\title{
A survey of larval digeneans in the commonest intertidal snails from Northern Patagonian coast, Argentina
}

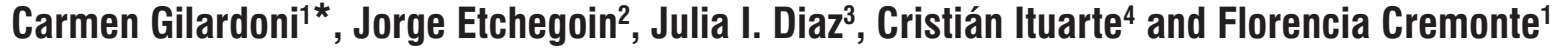 \\ ${ }^{1}$ Centro Nacional Patagónico, Boulevard Brown 2915, U9120ACD Puerto Madryn, Chubut, Argentina; ${ }^{2}$ Laboratorio de Parasitología, \\ Facultad de Ciencias Exactas y Naturales, Universidad Nacional de Mar del Plata, Funes 3350, 7600 Mar del Plata, Argentina; \\ ${ }^{3}$ Centro de Estudios Parasitológicos y de Vectores (CCT La Plata, CONICET-UNLP), Calle 2 \#584, 1900 La Plata, Argentina; \\ ${ }^{4}$ Museo Argentino de Ciencias Naturales (CONICET), Av. Ángel Gallardo 470, C1405DJR Buenos Aires, Argentina
}

\begin{abstract}
Over a two-years period, a survey was carried out in order to increase the knowledge of digeneans parasitising the commonest intertidal gastropods on the Patagonian coast, Southwestern Atlantic Ocean. A total of 4,725 gastropods were examined. Six species of digenean parasitising four snail species were found; four of them were registered for first time: Maritrema sp. 1 (Microphallidae) in Crepidula dilatata (Calyptraeidae), Parorchis sp. (Philophtalmidae) and sporocyst of Renicolidae in Trophon geversianus (Muricidae), and Diphterostomum sp. (Zoogonidae) in Buccinanops globulosus (Nassariidae). Two other species were found in Siphonaria lessoni (Siphonariidae): Maritrema sp. 2 and Hemiuridae. One snail species, Tegula patagonica (Trochidae) was not parasitised. These gastropods act as first intermediate host, and C. dilatata, S. lessoni and B. globulosus also frequently host metacercariae within the sporocyst. Overall prevalences varied from $0.16 \%$ of Diphterostomum in the intertidal population of B. globulosus to $33.45 \%$ of Maritrema sp. 1 in C. dilatata.
\end{abstract}

\section{Keywords}

Trematoda, Digenea, intertidal gastropods, larval stages, Patagonian coast

\section{Introduction}

Digeneans mainly use snails as first intermediate hosts, in which their parthenogenetic stages (sporocysts or rediae) develop (Yamaguti 1975, Galaktionov and Dobrovolskij 2003). These parasites may affect survival, behavior, reproductive function, phenotype and abundance or population structure of their hosts (e.g., Granovitch et al. 2000, Combes 2001, Galaktionov and Dobrovolskij 2003, Fredensborg et al. 2005). Furthermore, parasites are good markers of environmental stress, structure of food webs and biodiversity (Lafferty 1997, Marcogliese and Cone 1997, Lafferty et al. 2006).

The intertidal of Patagonian shores is a zone of high diversity that supports a rich fauna of invertebrates and birds (Balech and Ehrlich 2008), promoting the complex digenean life cycles. Despite the importance of digeneans in coastal marine areas, only six have been reported as infecting gastropods from the Southwestern Atlantic coast: a notocotylid cercaria from Laevilitorina caliginosa (Gould) (Littorinidae) (Graefe 1968), a lepocreadiid cercaria from Buccinanops monilifer (Kiener) and Buccinanops cochlidium (Dillwyn) (Nassariidae) (Martorelli 1991, Aberbuj and Cremonte 2010), a gymnophal- lid metacercaria from the patellids Nacella (Patinigera) magellanica (Gmelin) and Nacella (Patinigera) deaurata (Gmelin) (Martorelli and Morriconi 1998), a microphallid cercaria and metacercaria from the siphonariids Siphonaria lessoni (Blainville) and Kerguelenella lateralis (Gould), and schistosomatid and hemiurid cercariae from S. lessoni (Alda and Martorelli 2009).

Coasts of Nuevo Gulf in northern Patagonia have extensive sandy and rocky intertidal zones with a gradual slope. The commonest species of gastropods are Crepidula dilatata Lamarck (Calyptraeidae), living on vertical walls at lower intertidal levels, S. lessoni (Siphonariidade) inhabiting the entire intertidal zone, with the largest specimens located in the upper zone, Trophon geversianus Pallas (Muricidae) living on mussel beds, Buccinanops globulosus (Kiener) (Nassariidae) inhabiting lower sandy intertidal flats and Tegula patagonica (d'Orbigny) (Trochidae) occurring at lower intertidal rocky zones.

Bearing in mind the importance of digeneans in the life histories of marine snail hosts, the goal of the present study was to describe the larval digenean fauna affecting the commonest intertidal snails at Puerto Madryn, on the northern Patagonian coast, Argentina. 


\section{Materials and methods}

Snails were collected by hand during low tides from the intertidal of Punta Cuevas ( $\left.42^{\circ} 46^{\prime} \mathrm{S}, 64^{\circ} 54^{\prime} \mathrm{W}\right)$, Puerto Madryn, Chubut Province, Argentina. From November 2007 to October 2009, approximately 75 specimens of $C$. dilatata and 100 specimens of $S$. lessoni were monthly collected. Samples were randomly taken using a $12 \mathrm{~cm}^{2}$ square in order to include all size classes. From August 2008 to July 2010, monthly samples of about 30 specimens of each of T. geversianus, B. globulosus and T. patagonica were randomly collected along a transect perpendicular to the coast line. An additional sample of B. globulosus $(\mathrm{n}=59)$ was collected from the sandy shallow subtidal at the same beach.

Gastropods were transported to the laboratory and placed in small flasks filled with seawater at room temperature (20 $23^{\circ} \mathrm{C}$ ). Twice daily they were inspected under stereomicroscope looking for emerging of cercariae. Emerged cercariae were studied alive, stained with neutral red or Nile blue under a light microscope before being fixed. After 48 hs, all snails were necropsied in order to detect prepatent infections and to study sporocysts or rediae and metacercariae. The morphology was studied alive and photographed. The behaviour of emerged cercariae was studied in the flask under a stereomicroscope. The life span of cercariae was determinated at room temperature $\left(20-22^{\circ} \mathrm{C}\right)$ and at $10^{\circ} \mathrm{C}$.

Several naturally emerged cercariae, sporocysts, rediae and metacercariae were killed with heated seawater, immediately fixed with 10\% formalin (Cribb and Bray 2010), stained with acetic carmine, dehydrated through ascendant ethanol series, cleared with methylsalicylate and mounted on glass-slides with Canada balsam. Drawings and measurements (recorded for $\mathrm{n}=15-20$, unless otherwise indicated) were obtained from unflattened, fixed, stained and mounted specimens with the aid of a light microscope with drawing device. Measurements are presented in micrometers as mean values followed by the range in parentheses. Prevalences were calculated following Bush et al. (1997).

For scanning electron microscopy (SEM), larval digeneans were fixed in a $2.5 \%$ glutaraldehyde solution buffered with $0.1 \mathrm{M}$ sodium cacodylate, dehydrated through an ascendant ethanol series and dried by rinsing for few minutes in hexamethyldisilazane. Photomicrographs were obtained with a Jeol JSM-6460LV SEM operating at $15 \mathrm{KV}$.

Mounted specimens were deposited in the Helminthological Collection, Museo de La Plata (MLP), La Plata, and in the Parasitological Collection, Centro Nacional Patagónico (CNP-Par), Puerto Madryn, Argentina.

\section{Results}

A total of 4,725 gastropods were examined during a two-year period. Six species of digeneans, belonging to five families, were found parasitising C. dilatata, S. lessoni, T. geversianus, and B. globulosus. No parasites was found in T. patagonica $(n=689)$. The sites of infection of all intramolluscan larval stages found were the gonad and digestive gland.

Crepidula dilatata acted as first and second intermediate host for a species of Maritrema (Microphallidae). Siphonaria lessoni served as first and second intermediate host for $\mathrm{Ma}$ ritrema sp. 2 and also harboured sporocysts containing a cystophorous hemiurid cercaria. Trophon geversianus was parasitised by two digenean species, rediae with cercariae of Parorchis sp. (Philophtalmidae) and sporocysts with renicolid cercariae. Finally, Buccinanops globulosus was parasitised by sporocysts, cercariae and metacercariae of Diphterostomum sp. (Zoogonidae).

Family Microphallidae Travassos, 1920

Maritrema sp. 1 (Figs 1, 2, 7-11)

Sporocyst (Figs 1, 7, 8): Motionless, colourless, ovoid with anterior extremity often slightly pointed. Body 279 (160-379) long by 198 (130-279) maximum wide. Body wall 7 (5-10) thick. Movement of active cercariae may distort body shape; fully developed cercariae leave sporocyst via terminal birth pore. Two kinds of sporocysts observed, mother sporocysts filled only with germinal balls and daughter sporocysts containing germinal balls 6 (3-9), cercariae 9 (4-22) and/or metacercariae 7 (3-11). Sporocysts containing many germinal balls have few developed cercariae and vice versa. Total number of developing stages (germinal balls, cercariae, and metacercariae) per sporocyst 16 (6-31).

Cercaria (Fig. 2, 9-11): Monostome xiphidocercaria. Body small, elongate, 116 (93-143) long by 36 (26-49) maximum wide, uniformly covered with tiny spines from oral sucker to posterior end. Oral sucker subterminal, 22 (17-28) in diameter. Stylet well developed, lanceolate and refractive thickwalled in upper half, 18 (15-21) long by 6 (5-8) wide at base (Fig. 10). Ventral sucker absent. Four pairs of penetration glands irregular in shape, with nuclei near mid-body (Figs 2, 9); 2 anterior pairs sac-like with swollen ducts extending dorsally, opening on either side of ventral lip of oral sucker; 2 posterior pairs sac-like with thinner ducts extending ventrally and masked by dorsal ducts, opening on either side of stylet. Secretory material in anterior gland-ducts in form of rough grains, which stain with neutral red. In posterior gland-ducts, secretory material in form of small grains, not staining with neutral red (Fig. 9). Distance from anterior body end to posterior extremity of penetration glands 70 (66-77). Mouth and other parts of digestive system not developed. Excretory vesicle thin-walled, V-shaped, stem and arms shorts (Fig. 11). Excretory pore at tip of tail. Tail cylindrical and contractile, slightly shorter than the body, 87 (70-100) long by $11(9-15)$ wide at base, diameter decreasing towards distal end. Tegument with numerous annular folded membranes.

Behaviour: Under laboratory conditions, naturally emerged cercariae swim actively for a few minutes and then fall to the bottom. While swimming, the posterior extremity of the 


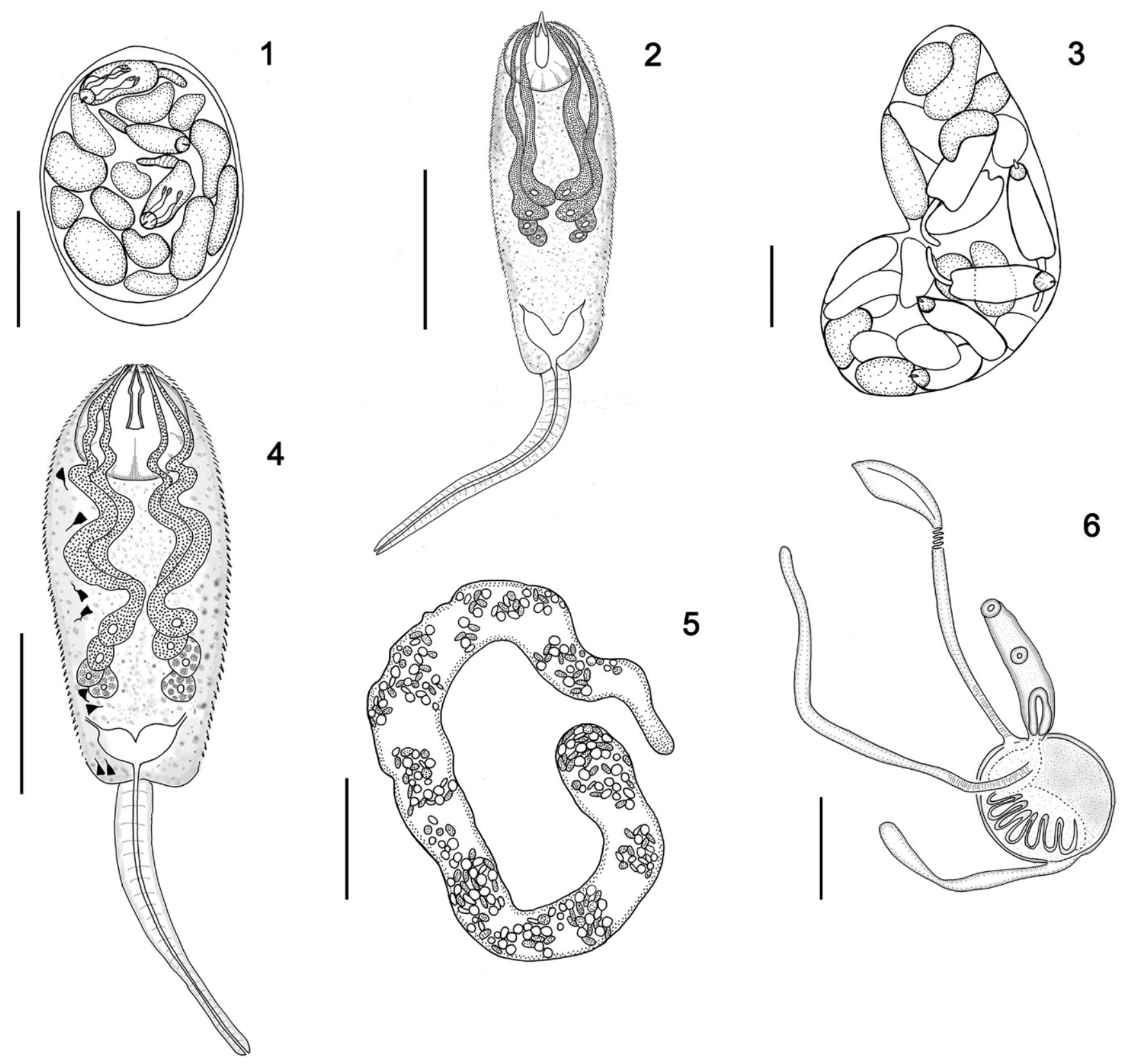

Figs 1-6. Line drawings: 1. Sporocyst of Maritrema sp. 1. 2. Cercaria of Maritrema sp. 1, dorsal view. 3. Sporocyst of Maritrema sp. 2. 4. Cercaria of Maritrema sp. 2, dorsal view, flame cells of right side omitted. 5. Sporocyst of Hemiuridae. 6. Cercaria of Hemiuridae. Scale bars $=50 \mu \mathrm{m}(2,4), 100 \mu \mathrm{m}(1,3,6), 500 \mu \mathrm{m}(5)$

cercarial body is bent ventrally and tail lies parallel to the ventral body surface. Cercariae move alternating body contractions with vigorous tail lashes. Their life-span is less than $24 \mathrm{hs}$ at room temperature, but at $10^{\circ} \mathrm{C}$ survive up to $48 \mathrm{hs}$.

Metacercaria: Spherical cyst, 74 (67-80) long by 69 (6375 ) wide, wall 5 (3-6) thick. Under laboratory conditions cercariae encyst inside sporocyst; cercaria gradually cease movement, becoming rounded and secreting a thin wall.

Host: Crepidula dilatata Lamarck (Caenogastropoda, Calyptraeidae).

Prevalence: $33.45 \%(n=1,665)$.
Specimens deposited: 6285 (MLP) and 28 (CNP-Par).

Comments: The following characteristics define the described cercaria as belonging to the Microphallidae: oral sucker with a poorly defined musculature and prominent stylet (xiphidocercaria); ventral sucker absent (monostoma cercaria); tegument spined; digestive system undeveloped (anenteric cercaria); excretory vesicle V-shaped and tail small and simple (leptocercous cercaria). The cercaria belongs to the genus Maritrema Nicoll, 1907 because of the shape and location of penetration glands (Bridgman 1971). This is a third report of a Maritrema parthenitae in snails from Argentina. 

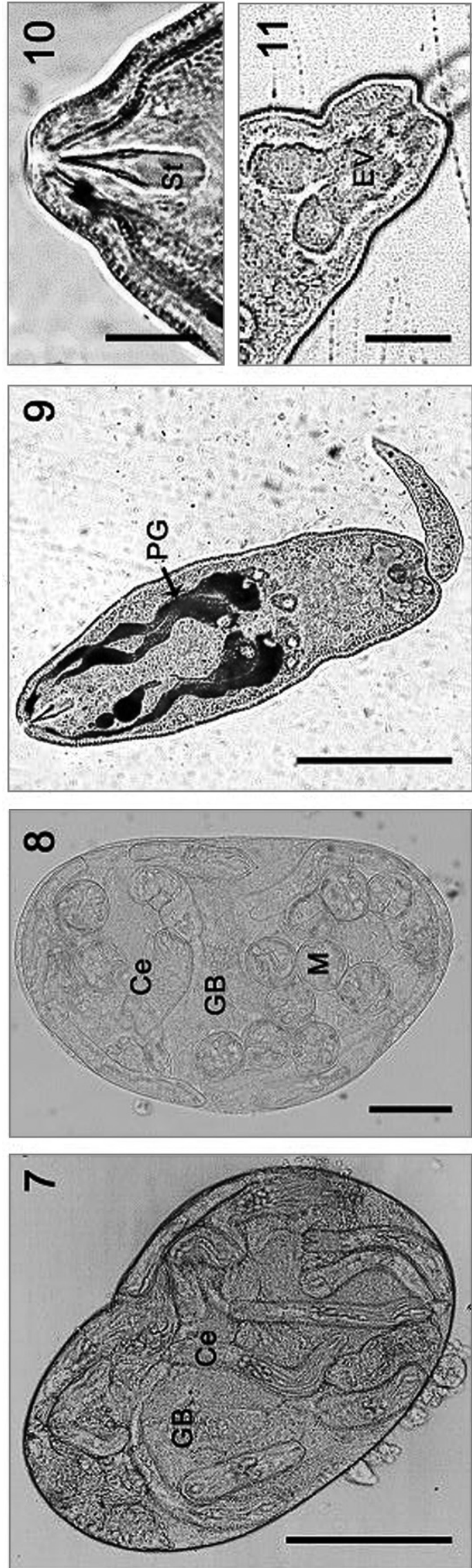
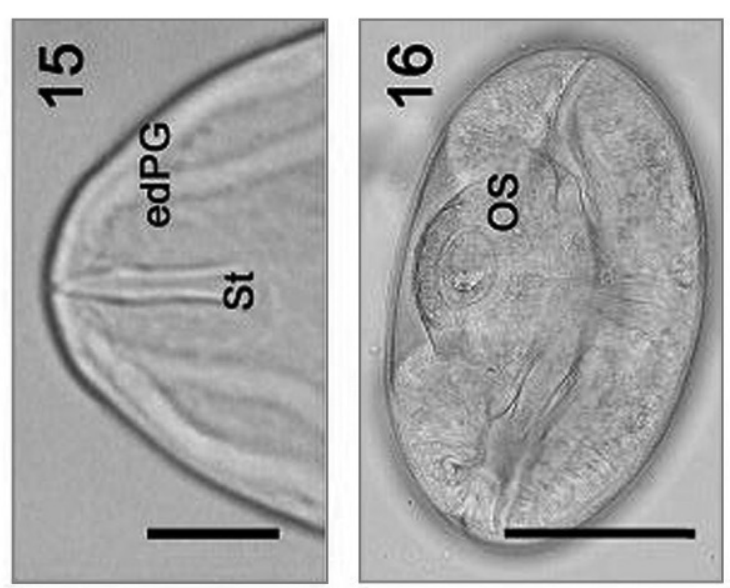

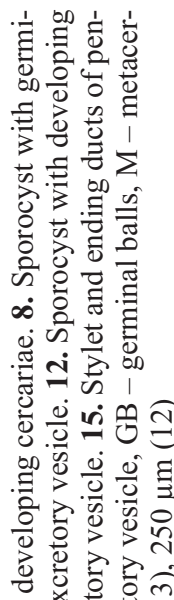

चี

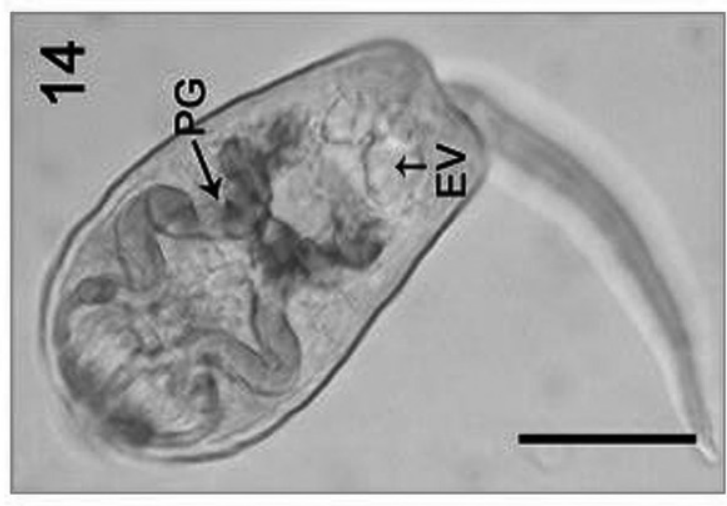

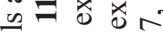

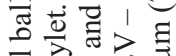

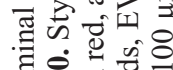

틍은

on

责宁

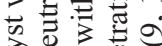

证

敋要

क. उृ n

$\circ$ 拝

इे की on
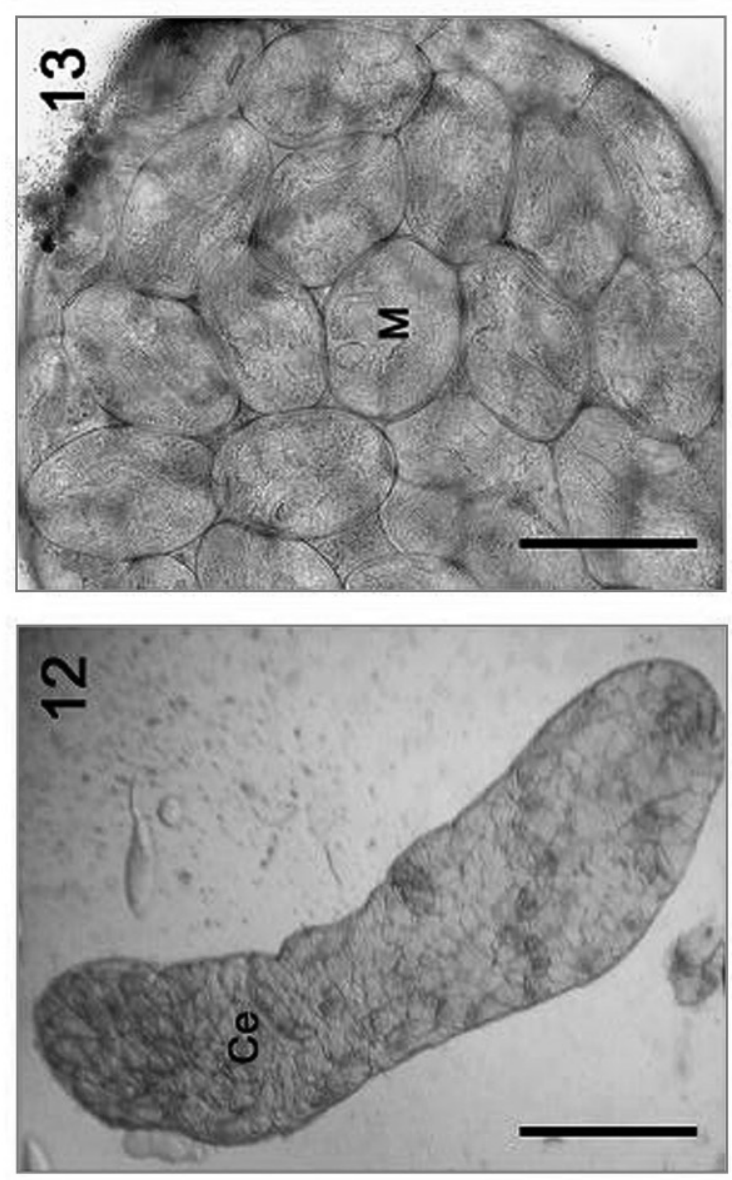

6 का

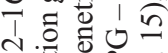

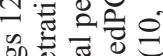

远行

글 흉

की

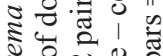

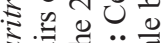

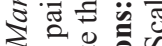

宗导

=

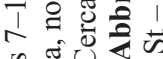

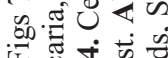

迅哥さ菏

U \&

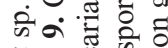

ङ

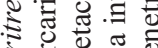

施

出曹考苛

品专

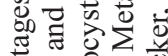

की

हो जी की

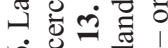

1 这

50 
Previously, Etchegoin and Martorelli (1997) described Maritrema bonaerensis Etchegoin et Martorelli, 1997 from the brackish water snail Heleobia australis d'Orbigny (Cochliopidae) from Mar Chiquita coastal lagoon $\left(37^{\circ} 46^{\prime} \mathrm{S}, 57^{\circ} 27^{\prime} \mathrm{W}\right)$. In addition, Alda and Martorelli (2009) described Maritrema sp. 2 parasitising Siphonaria lessoni and Kerguelenella lateralis Gould (Siphonariidae) from the rocky intertidal at Comodoro Rivadavia ( $\left.45^{\circ} 51^{\prime} \mathrm{S}, 67^{\circ} 29^{\prime} \mathrm{W}\right)$, Chubut Province.

Maritrema sp. 2 (Figs 3, 4, 12-16)

Sporocyst (Figs 3, 12, 13): Body elongate, light yellowish, motionless, 709 (520-1000) long by 245 (170-290) maximum wide. Movement of active cercariae may distort body shape; fully developed cercariae leave sporocyst via terminal birth pore. Two kinds of sporocysts observed; sporocysts with germinal balls and cercariae at different developmental stages or sporocysts filled with metacercariae (Fig. 13). Total number of larval stages per sporocyst (germinal balls, cercariae, and metacercaria) 37 (15-50).

Cercaria (Figs 4, 14, 15): Monostome xiphidocercaria. Body small, elongate, 132 (105-200) long by 52 (48-70) maximum wide, uniformly covered with tiny spines from oral sucker to posterior end. Oral sucker subterminal, 34 (29-38) in diameter. Stylet well developed 18 (14-22) long by 4 (2.54.5 ) wide at base, arrow-shaped with refractive layer, wide at base with anterior end pointed (Fig. 15). Ventral sucker absent. Four pairs of penetration glands irregular in shape, with nuclei in posterior part of body; 2 anterior pairs sac-like with swollen ducts extending dorsally, forming three loops and opening on either side of ventral lip of oral sucker; 2 posterior pairs saclike with thinner ducts extending ventrally and masked by dorsal ducts, opening on either side of stylet (Figs 4, 14). Secretory material in anterior gland-ducts in form of rough grains, which stain with neutral red and in posterior glandducts in form of small grains, not staining with neutral red. Distance from anterior body end to posterior extremity of penetration glands 93 (82-109). Mouth and other parts of digestive system not developed. Excretory vesicle thin walled, V-shaped, stem and arms short (Fig. 14). Excretory formula: $2[(2+2)+(2+2)]=16$. Excretory pore at tip of tail. Tail cylindrical and contractile, shorter than body, 103 (95-125) long by $10(8-11)$ wide at base, diameter decreasing towards distal end. Tegument provided with numerous annular folds.

Behaviour: Movement and life-span similar to Maritrema sp. 1.

Metacercaria (Fig. 16): Oval cyst, 74 (65-85) long by 125 (110-135) wide, with hyaline layer 10 (7-13) thick. Pharynx, caeca and spinous cirrus, present.

Host: Siphonaria lessoni Blainville (Pulmonata, Bassommatophora, Siphonariidae).

Prevalence: $8.95 \%(\mathrm{n}=1,050)$.

Specimens deposited: 6284 (MLP) and 27 (CNP-Par).

Comments: Maritrema sp. 2 was described by Alda and Martorelli (2009) from S. lessoni and K. lateralis at the inter- tidal of Comodoro Rivadavia, about $500 \mathrm{~km}$ south of the present locale. Maritrema sp. 2 differs from Maritrema sp. 1 in the body size, the shape of the stylet and the location of the penetration glands and ducts. Sporocysts of Maritrema sp. 2 are larger than those of Maritrema sp. 1 and bear a larger number of larval stages (37 vs 16). The stylet is of similar size (18), although in Maritrema sp. 1 is it lanceolate and covered with a refractive layer at the pointed anterior end, and in Maritrema sp. 2 it is arrow shaped and is entirely covered by a refractive layer. The nuclei of the penetration glands are situated near the middle of the body in Maritrema sp. 1 and near the posterior end in Maritrema sp. 2. Metacercariae of Maritrema sp. 1 were found developing inside the sporocyst mainly under laboratory conditions; whereas sporocysts of Maritrema sp. 2 were usually found filled with encysted metacercariae. Maritrema sp. 2 is most similar to M. bonaerensis in the size of the larval stages and the shape of the stylet. However, the species differ in the position of the nuclei of the penetration glands and in the loops of the ducts. In the latter characters, M. bonaerensis is similar to Maritrema sp. 1 (Etchegoin and Martorelli 1997).

\section{Family Hemiuridae Looss, 1899 (Figs 5, 6, 17-20)}

Sporocyst (Figs 5, 17, 18): Body long, elongate, irregularly shaped, with anterior end narrow and posterior end slightly expanded, 4,461 $(2,700-7,410)$ long by $269(180-310)$ wide. Terminal birth pore long and narrow (Fig. 17). Number of cercariae per sporocyst $250(130-400)$.

Cercaria (Figs 6, 19, 20): Cystophorous, elongate body 138 (117-162) long by 27 (22-30) wide, developing in spherical caudal cyst, 105 (92-128) in diameter. Delivery tube attached at posterior end of cyst cavity, slightly flattened, 329 (267$369)$ long $(\mathrm{n}=3)$, with median longitudinal furrow and apical finfold on each side. Excretory vesicle epithelial, 43 (32-50) long by 21 (14-26) wide. Oral sucker $20(15-25)$ in diameter and ventral sucker 16 (14-20) in diameter. Pharynx, oesophagus and intestinal caeca not observed. Two caudal filaments at both side of cyst, thin and delicate, one longer, 416 (320 490) long another shorter 226 (196-290) long.

Behaviour: Natural cercarial emergence was not observed. Larvae were obtained from sporocysts; after leaving the sporocyst, cercariae moved slowly for a few minutes.

Host: Siphonaria lessoni Blainville (Pulmonata, Bassommatophora, Siphonariidae).

Prevalence: $0.48 \%(\mathrm{n}=1,050)$.

Specimens deposited: 6283 (MLP) and 26 (CNP-Par).

Comments: This cystophorous cercaria belongs to the family Hemiuridae. Three cercariae of this family have been reported from Argentinean waters: Genarchella genarchella in Heleobia parchappei d'Orbigny (Cochliopidae), and cystophorous cercariae in Potamolithus agapetus Pilsbry (Cochliopidae) from lagoons at Buenos Aires Province (Martorelli 1989, 1994) and in Siphonaria lessoni from Patagonian coast at Comodoro Rivadavia, Chubut Province (Alda and Mar- 

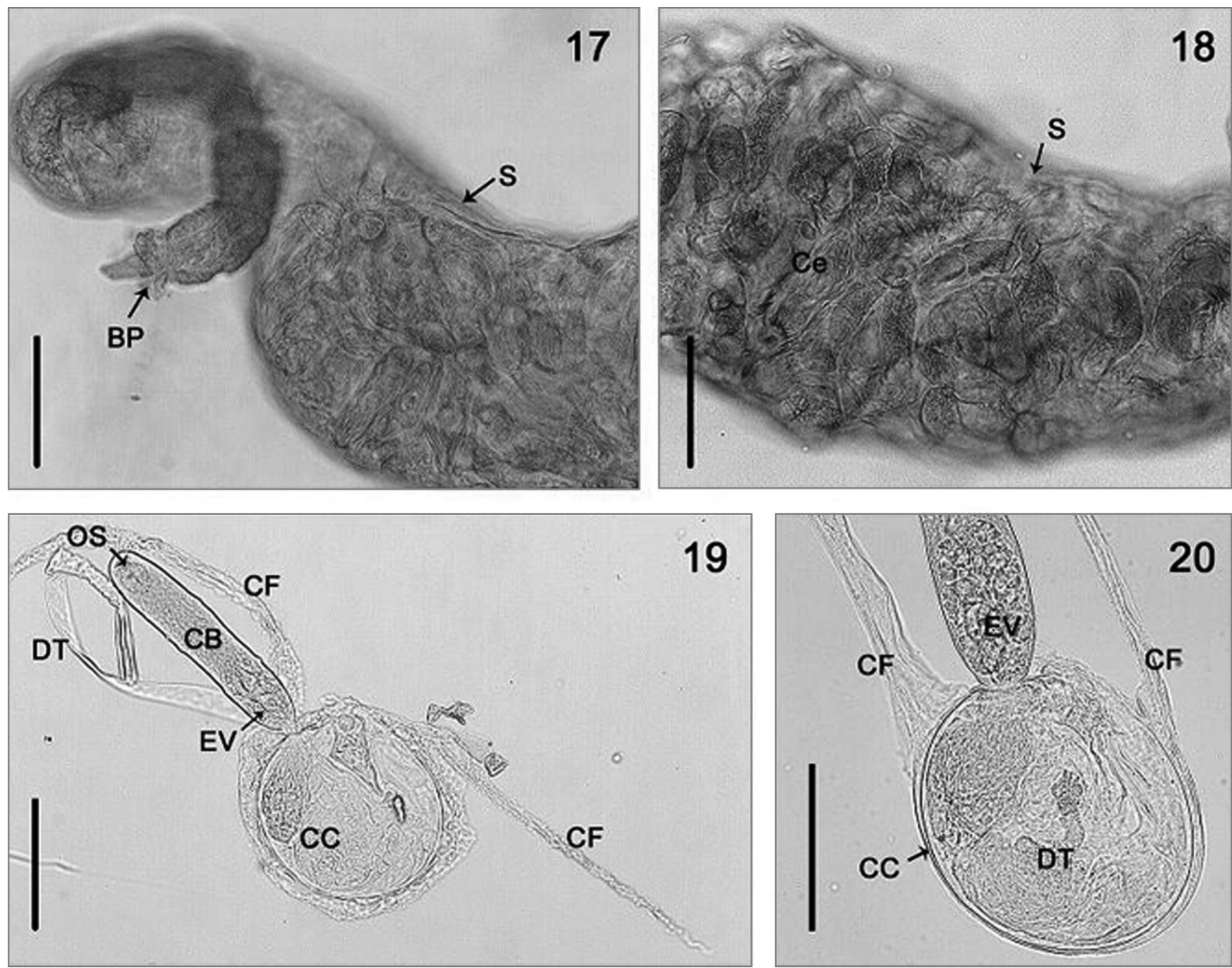

Figs 17-20. Larval stages of Hemiuridae (Figs 17-18 in toto, Figs 19-20 in vivo). 17. Anterior end of sporocyst with developing cercariae. 18. Sporocyst. 19. Cercaria. 20. Detail of caudal cyst with delivery tube inside. Abbreviations: $\mathrm{BP}$ - birth pore, $\mathrm{Ce}-\mathrm{cercaria}, \mathrm{CB}-\mathrm{cercar}-$ ial body, CC - caudal cyst, CF - caudal filament, DT - delivery tube, EV - excretory vesicle, OS - oral sucker, S - sporocyst. Scale bars = $50 \mu \mathrm{m}(20), 100 \mu \mathrm{m}(17-19)$

torelli 2009). The larvae here described are probably the same as reported from Comodoro Rivadavia; however, in the specimens here examined, 2 caudal filaments were observed.

Family Philophtalmidae Travassos, 1918

Parorchis sp. (Figs 21, 22, 27-41)

Redia (Figs 21, 27, 34-36): Body large, elongate, 1,128 (620$1,350)$ long by $271(140-380)$ maximum wide. Birth pore anterior and lateral (Fig. 35); wall 9 (6-16) thick. Pharynx small, $83(38-135)$ long by $67.5(32-110)$ wide. Intestine saccular, $273(180-340)$ long by $43(35-60)$ wide $(n=5)$, orange in colour. Usually, 10 (8-14) embryos per redia at different developmental stages, 5 (4-9) cercariae and $4(2-8)$ germinal balls.

Cercaria (Figs 22, 28-33, 37-40): Echinostome-like cercaria. Body spinous, 328 (260-408) long by $172(130-230)$ wide at level of ventral sucker. Numerous cystogenous glands from pharynx to body end, staining well with neutral red, filled with granular inclusions (Figs 28, 33). Oral sucker 49 (36-60) long by 58 (50-70) wide. Mouth subterminal, surrounded by an outer circle of 12 papillae and an inner circle of 8 papillae (only seen at SEM, Fig. 40). Collar with about 77 spines per row, interrupted ventrally (Figs 22, 38). Prepharynx short, pharynx muscular $52(28-80)$ long by $39(24-55)$ wide $(\mathrm{n}=$ $10)$, oesophagus long, bifurcating anterior to ventral sucker. Intestinal caeca narrow, $119(62-156)$ long $(n=3)$ extending to level of excretory vesicle. Ventral sucker at mid-ventral level of body, 73 (46-93) long by $78(60-105)$ wide, with an inner circle of 8 papillae (only seen at SEM, Fig. 40). Body covered with spines, except around ventral sucker (Figs 29, 37). Two longitudinal rows of papillae distributed dorsally and ventrally from anterior end to ventral sucker level and group of papillae scattered from collar spine to anterior end (only 

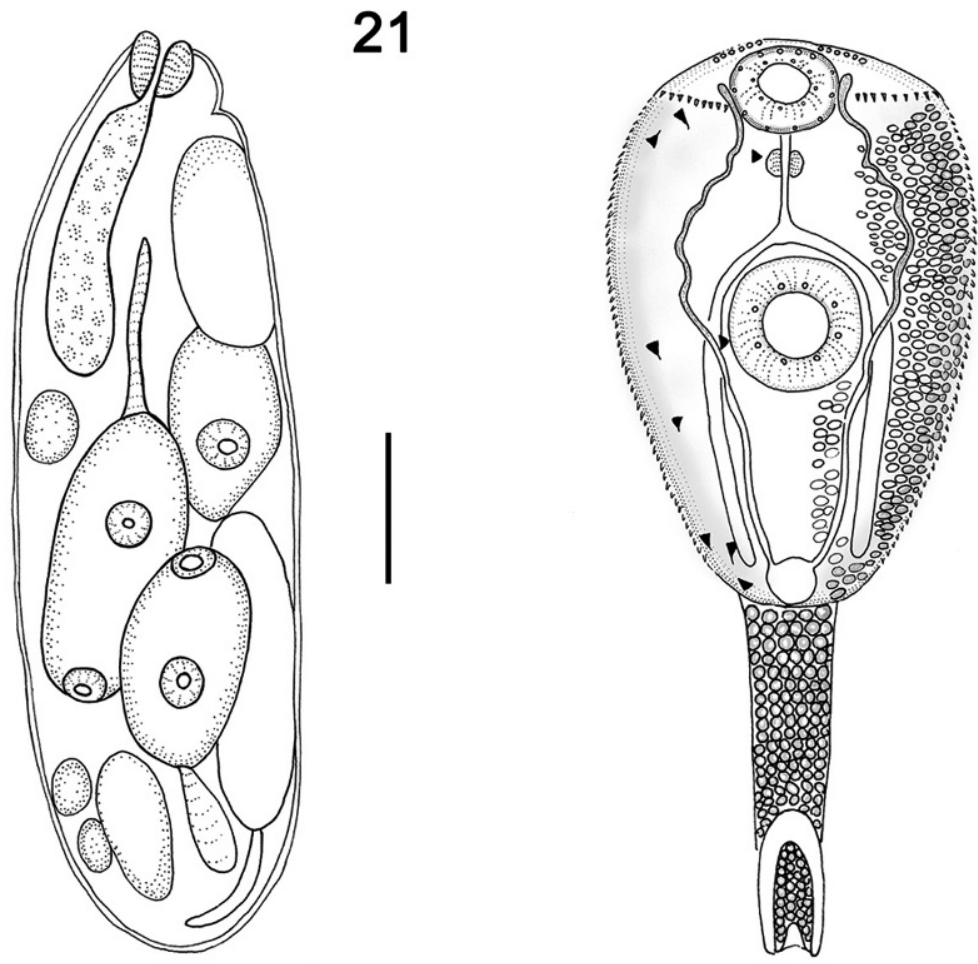

22

23
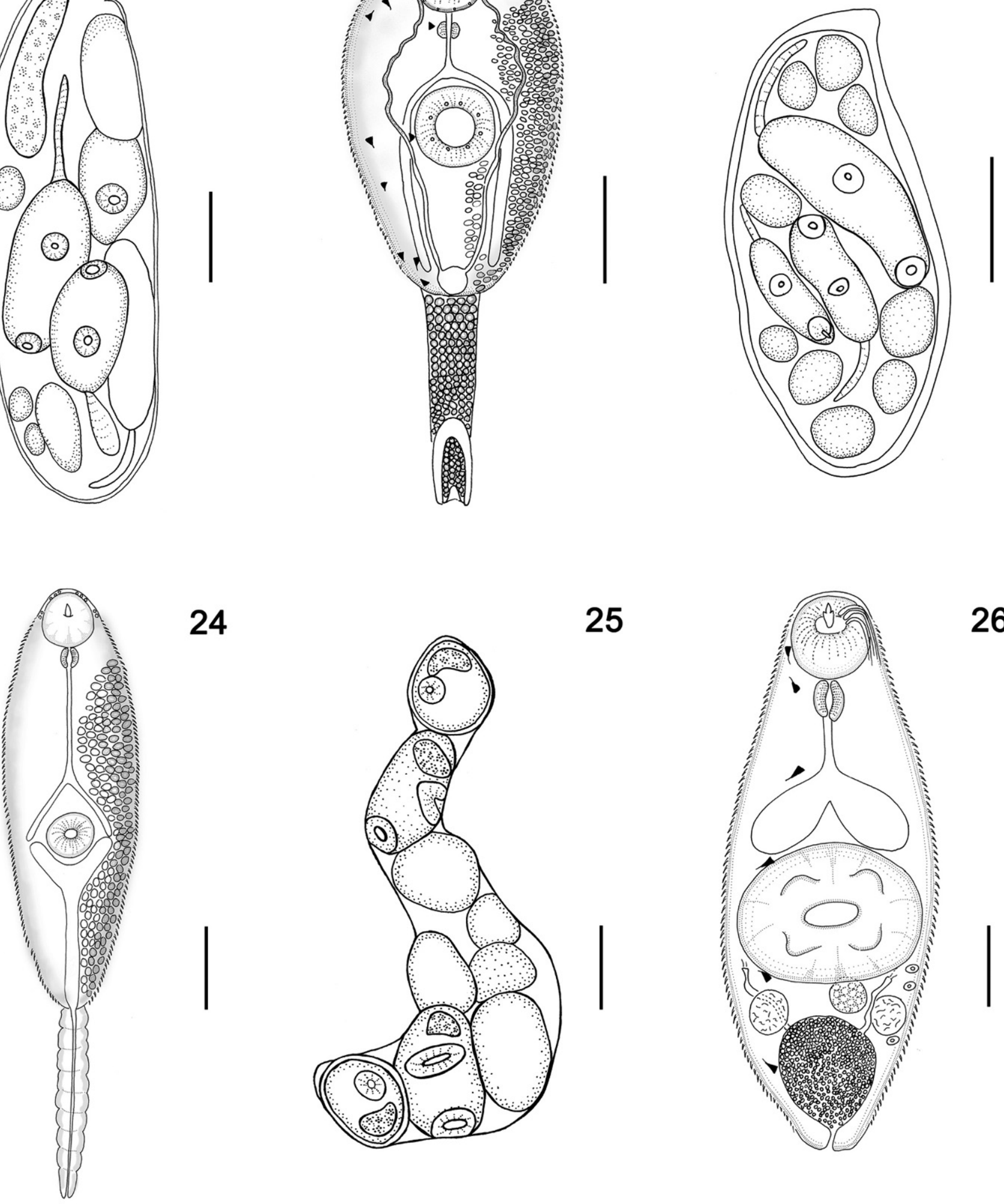

Figs 21-26. Line drawings: 21. Redia of Parorchis sp. 22. Cercaria of Parorchis sp., ventral view, flame cells of left side and cystogenous cells of right side omitted. 23. Sporocyst of Renicolidae. 24. Cercaria of Renicolidae. 25. Sporocyst of Diphterostomum sp. 26. Cercaria of Diphterostomum sp., ventral view, flame cells of left side omitted. Scale bars $=50 \mu \mathrm{m}(24,26), 100 \mu \mathrm{m}(22,23,25), 200 \mu \mathrm{m}(21)$ 

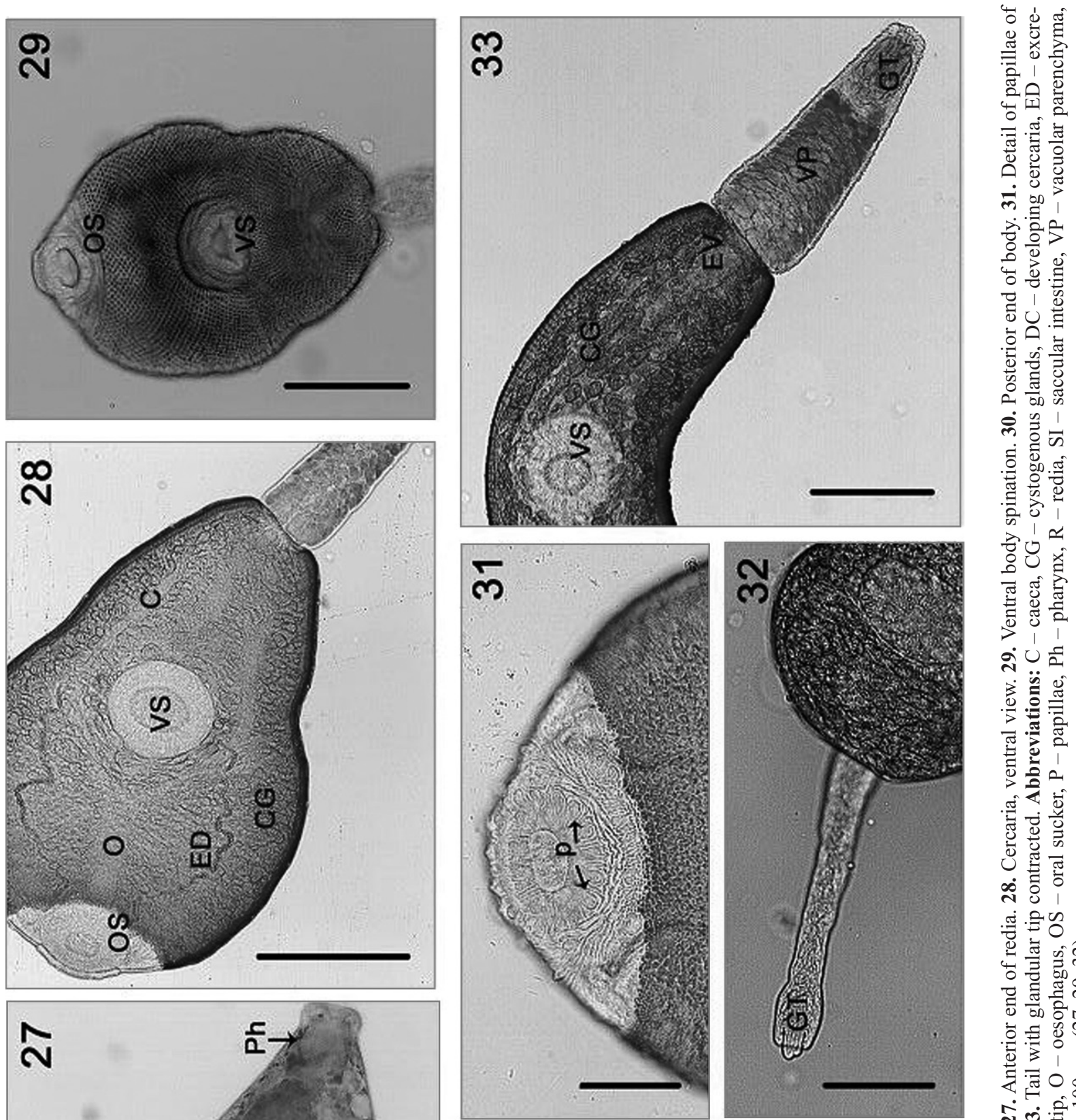

궁

퓰 류 है จ่บ 宅泀芯 元势

苞

$>20$

哥它

过苞

ஸें ठํ

预朋

离

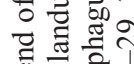
का को क्ष .

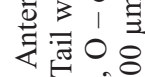

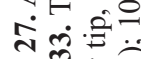
ㅁํㄹ

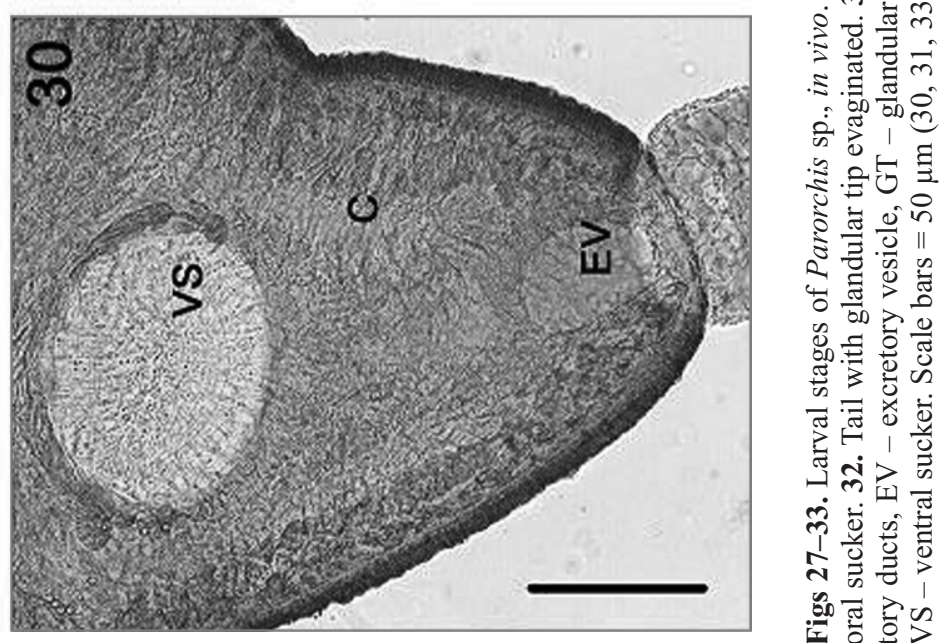



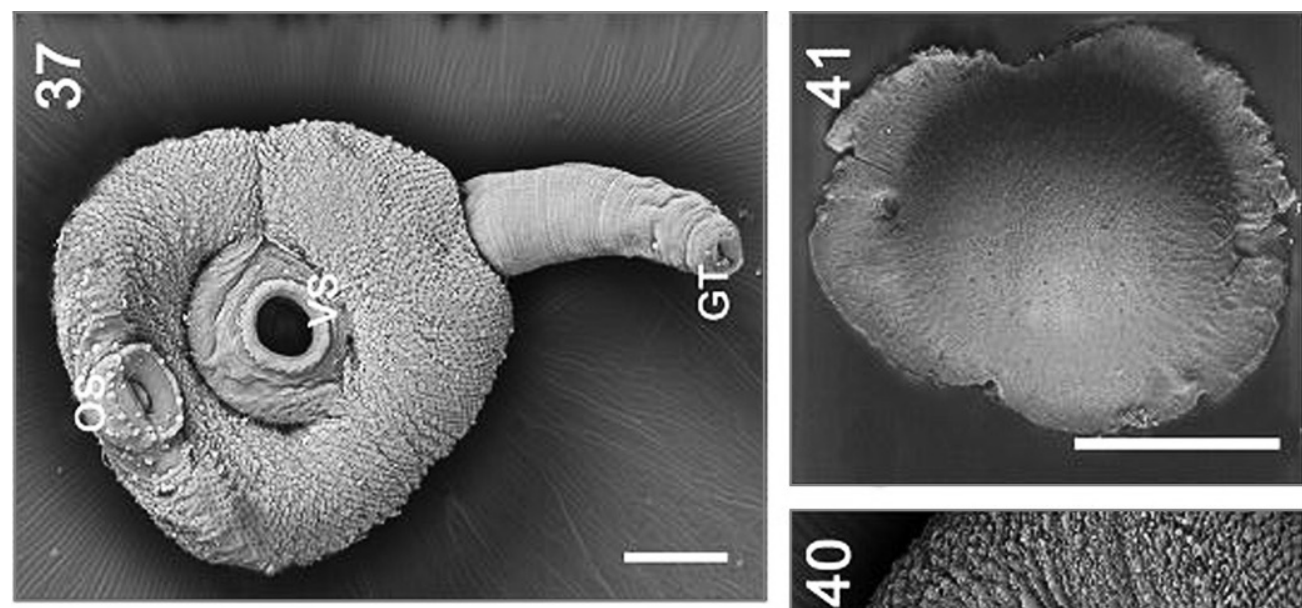

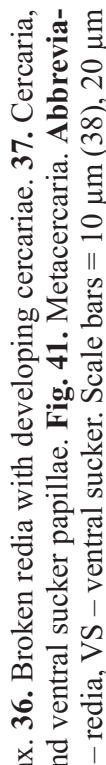
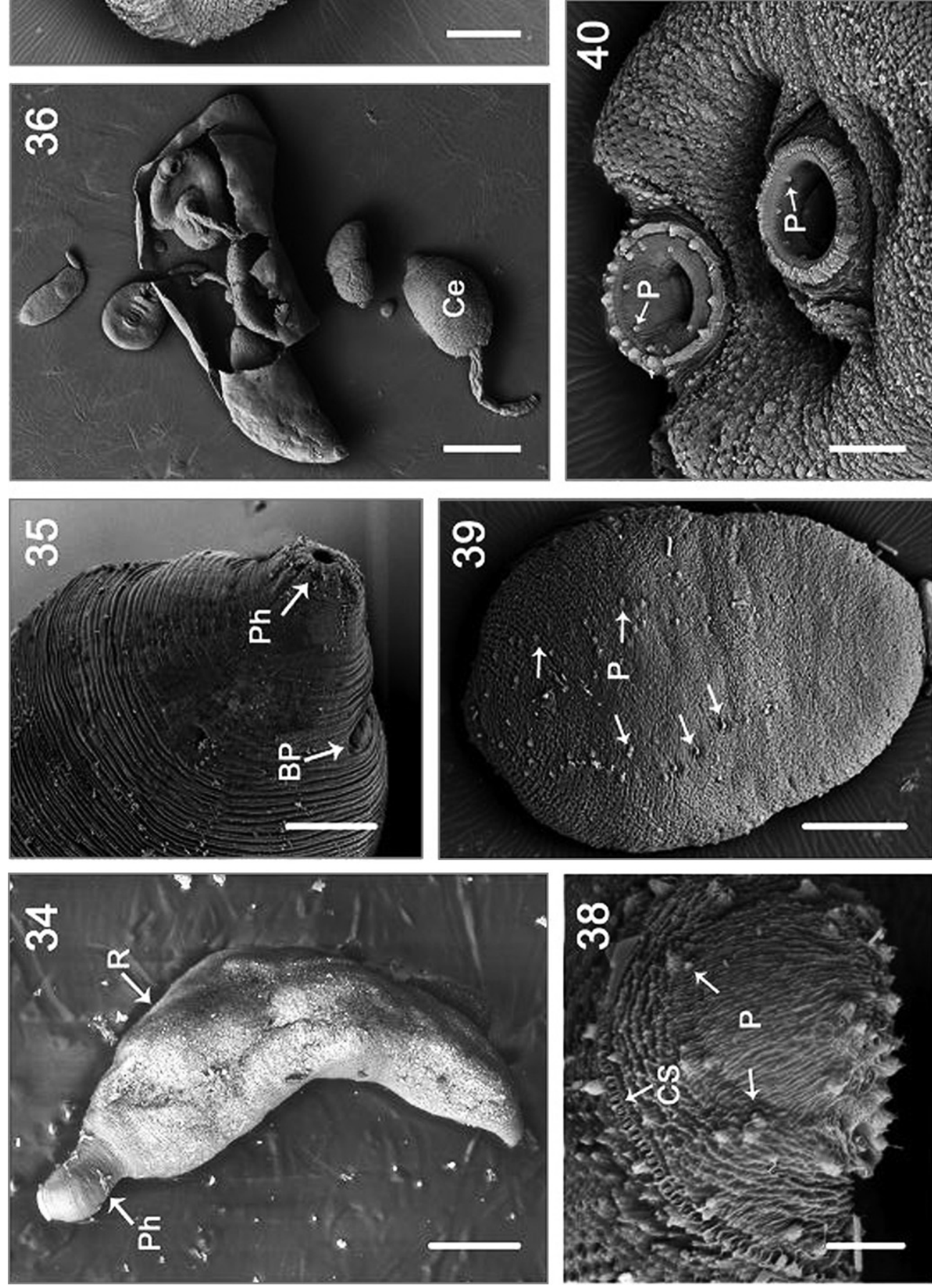

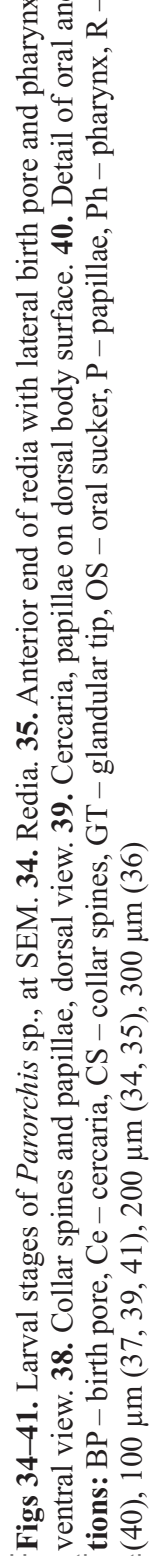


seen at SEM, Fig. 39). Six pairs of penetration glands opening dorsally at anterior end of body; none of these glands stained with neutral red; cytons and ducts masked by cystogenous glands. Excretory vesicle small, spherical; limbs extending straight to middle of ventral sucker and then as irregulary sinuous ascending tubules reaching posterolateral margins of oral sucker (Figs 28, 30). Limbs with minutes spherical concretions from ventral sucker level to pharynx level. Excretory formula: $2[(3+3+3)]=18$. Tail $303(200-455)$ long by 52 (40-60) wide at base, with vacuolar parenchyma, ending in a glandular tip (Figs 32, 33, 37).

Behaviour: Under laboratory conditions, naturally emerged cercariae swim for a few minutes, undulate the body with quick contracting and stretching movements. Then, cercariae fall to the bottom, creeping and attaching with the aid of ventral sucker, being very difficult to dislodge with pipette suction; then rapidly encyst. After attachment to the substrate, secretions from cystogenous cells form the cyst. Life-span is about $24 \mathrm{hs}$ at room temperature, but at $10^{\circ} \mathrm{C}$ survival is up to 72 hs.

Metacercaria (Fig. 41): Cyst slightly oval, flattened on side of attachment, 234 (212-260) long by 204 (198-213) wide, with two-layer wall. Outer wall $9(8-10)$ thick, inner wall 13 (8-19) thick.

Host: Trophon geversianus Pallas (Caenogastropoda, Muricidae).

Prevalence: $0.87 \%(n=689)$.

Specimens deposited: 6282 (MLP) and 24-25 (CNP-Par).

Comments: The following characteristics define the described cercaria as belonging to the Philophtalmidae and are diagnostic for the genus Parorchis Nicoll, 1906: echinostomelike cercaria, with collar spines, glandular invaginated tip of tail and metacercarial cyst slightly oval found on the substrate. There are at least seven previous descriptions of cercariae belonging to Parorchis, all from the Northern Hemisphere (e.g., Nicoll 1907, Cable 1963, Lauckner 1980). These descriptions were extensively discussed because cercariae present only slight morphological differences (e.g., Stunkard and Cable 1932, Holliman 1961). This is the first record of philophtalmid parthenitae from South America.

\section{Family Renicolidae Dollfus, 1939 (Figs 23, 24, 42-50)}

Sporocyst (Figs 23, 42): Oval, 381 (227-502) long by 207 (132-330) wide, wall 10 (6-15) thick, anterior end narrow, containing 10 (2-24) germinal balls and $5(1-8)$ cercariae; total number of larval per sporocyst 13 (3-27). Birth pore terminal.

Cercaria (Figs 24, 43-50): Distome xiphidocercaria. Body elongate, 258 (197-286) long by 58 (46-77) wide, covered with tiny spines from oral sucker to posterior end, more scattered behind ventral sucker. Four rows of longitudinal papillae on ventral surface, from oral sucker to ventral sucker (only seen at SEM, Fig. 47). Cystogenous glands filling the parenchyma from level of pharynx to posterior end of body, most dense at sides (Fig. 45). Oral sucker subterminal, 37 (2244) long by 25 (18-42) wide, with 4 groups of 3 papillae around mouth (seen at SEM, Fig. 48). Stylet small, lanceolate, 7 (6-8) long by 2 (1-3) wider at base (Fig. 43). Ventral sucker 27 (20-32) long by 21 (16-30) wide, with 2 concentric rows of spines (only seen at SEM, Fig. 50). Five pairs of penetration glands; ducts of 3 pairs opening dorsally close to stylet, 2 pairs opening ventro-laterally to oral sucker. Nuclei of penetration gland-cells not observed, masked by cystogenous glands. Prepharynx absent, pharynx $11(9-13)$ long by 9 (712) wide, oesophagus 50 (35-55) long; caeca, 45 (35-52) long reaching mid-level of ventral sucker. Excretory vesicle Yshaped with long stem and short arms reaching mid-level of ventral sucker (Figs 24, 44), opening at tip of tail. Excretory cells not observed, masked by cystogenous glands. Tail 135 (104-164) long by 19 (16-24) wider at base.

Behaviour: Under laboratory conditions, naturally shed cercariae swim for several hours with vigorous movements of the body, bending the posterior body end downward and tail vibrating laterally. On the bottom, cercariae maintain the ventral face upward and tail bent over the body. Their life-span is about 48 hs at room temperature.

Host: Trophon geversianus Pallas (Caenogastropoda, Muricidae).

Prevalence: $0.29 \%(\mathrm{n}=689)$.

Specimens deposited: 6278-6279 (MLP) and 20 (CNPPar).

Comments: The following morphological features define the parthenitae here described as belonging to Renicolidae: xiphidocercaria (with stylet present), Y-shaped excretory vesicle, prepharynx absent and cystogenous glands numerous. This is the first report of renicolid parthenitae from South America. At least 23 renicolid cercariae have been described worldwide (Cable 1956, Sannia and James 1977, Galaktionov and Skirnisson 2000, Martorelli et al. 2008).

Family Zoogonidae Odhner, 1902

Diphterostomum sp. (Figs 25, 26, 51-60)

Sporocyst (Figs 25, 56, 57): Body elongate, motionless, yellowish, $962(530-1,420)$ long by $222(170-260)$ wide, body wall 6 (2-14) thick; movement of cercariae may distort body shape. Three types of sporocysts observed: (a) filled with germinal cells and developing cercariae, (b) filled with metacercariae or (c) filled with both stages. Total number of larval stages (cercariae and metacercariae) 7 (6-11).

Cercaria (Figs 26, 51-55, 58-60): Tailless xiphidocercaria, small and elongate body, 323 (263-392) long by $120(90-160)$ wide, entire body covered with minute spines (Figs 51, 60). Cystogenous cells scattered in parenchyma. Oral sucker subterminal, 63 (50-76) long by 50 (36-69) wide. Stylet small, lanceolate, 14 (12-20) long by 4 (3-6) wide at base (Fig. 52). Prepharynx absent, pharynx globose, $26(22-30)$ long by 21 (20-23) wide $(\mathrm{n}=3)$, oesophagus short, bifurcating into two short saccular intestinal caeca, 55 (46-66) long $(n=5)$, not 

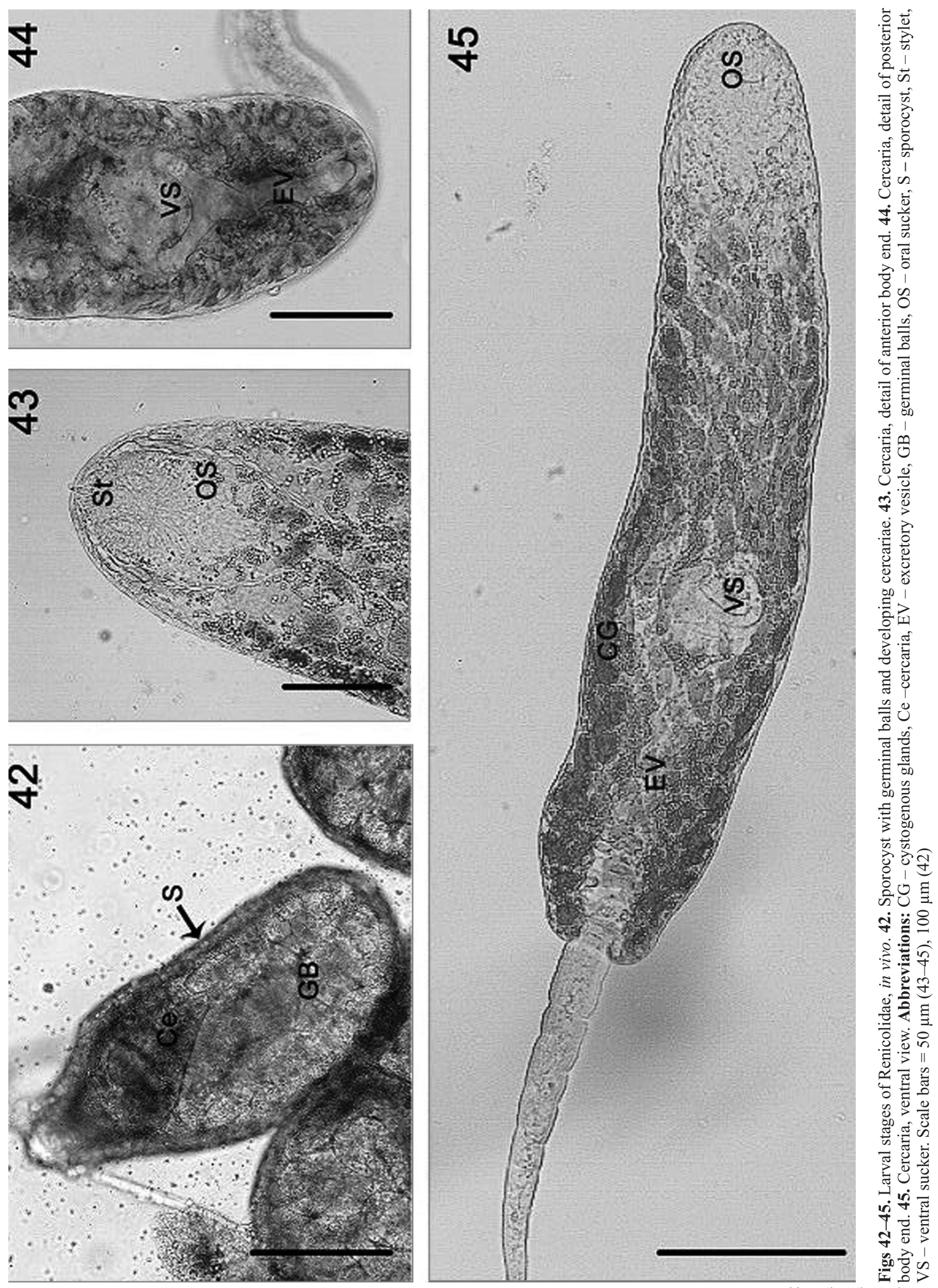

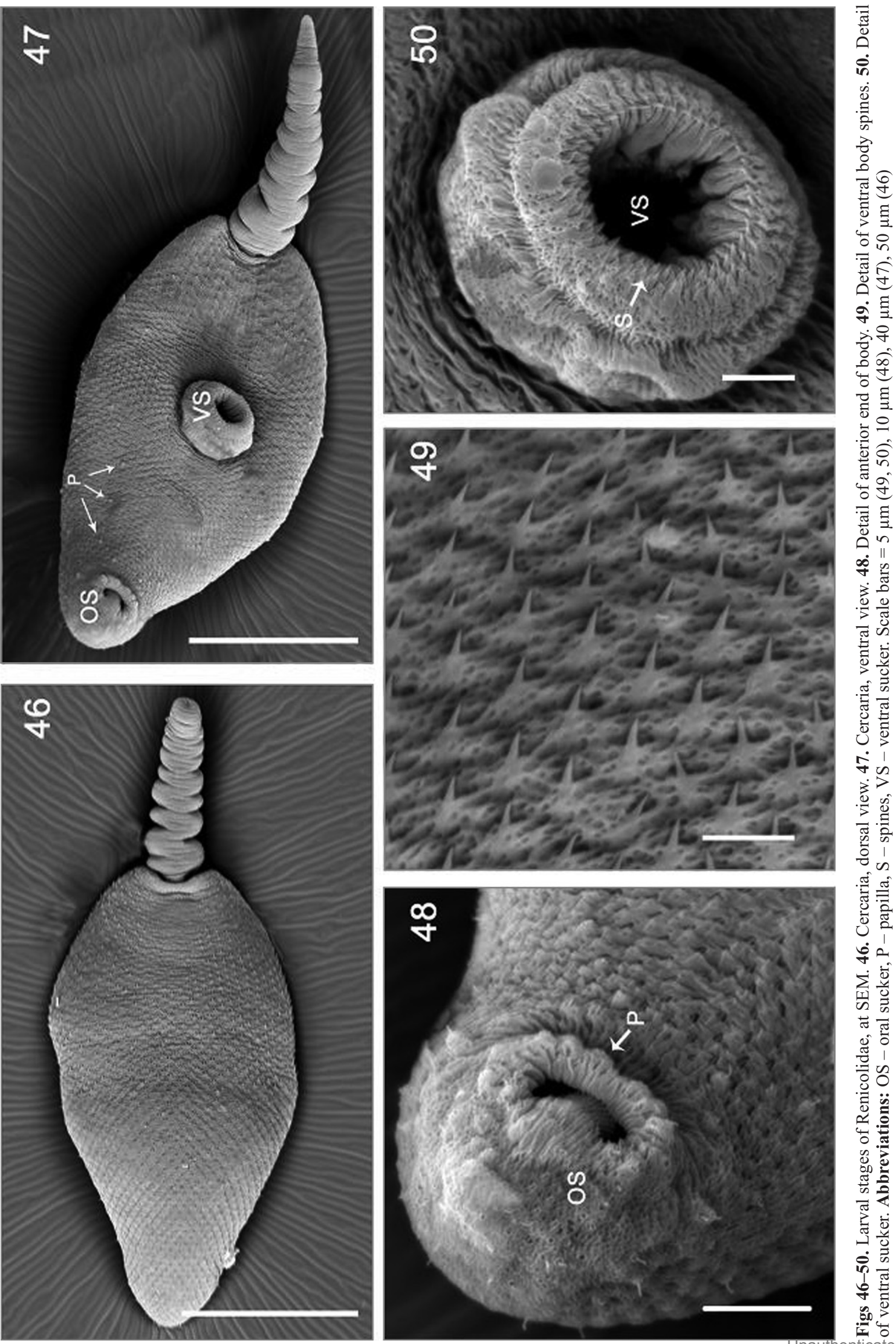

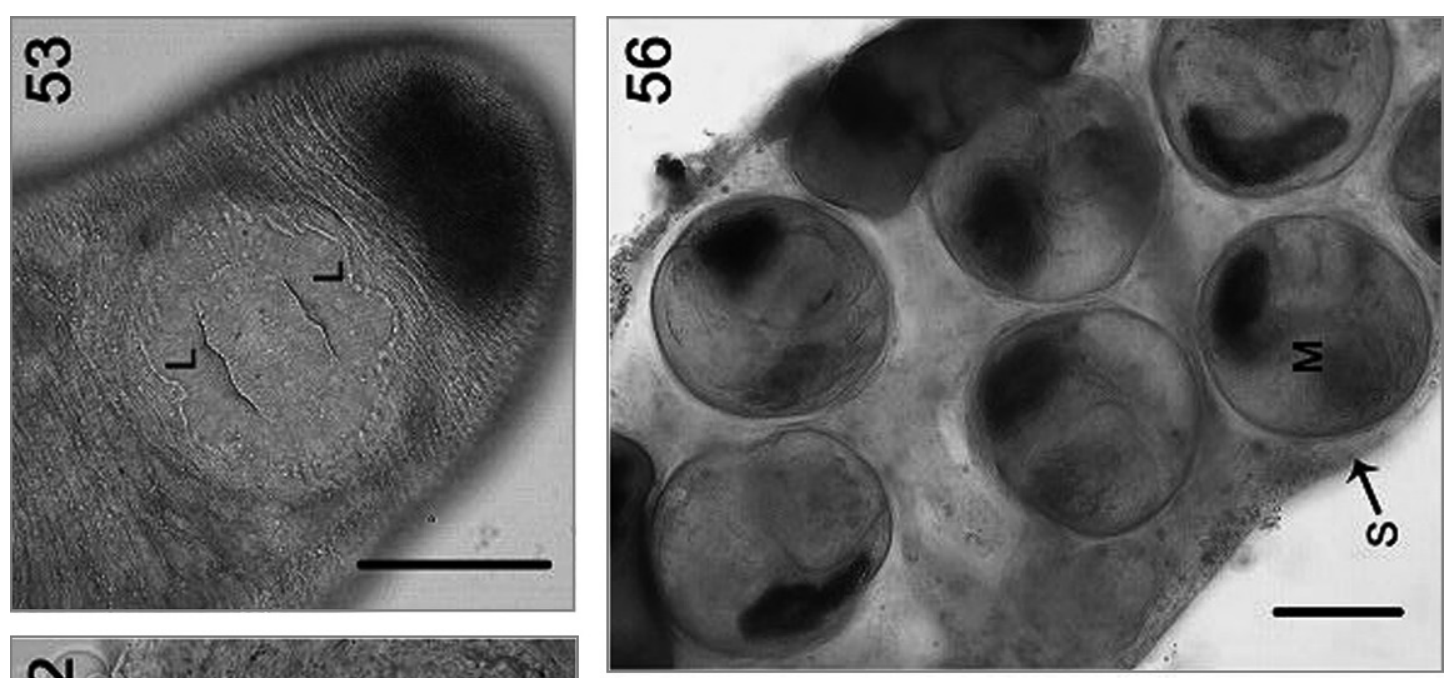

党

究

东政

in

要>

齿

言部

पे

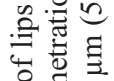
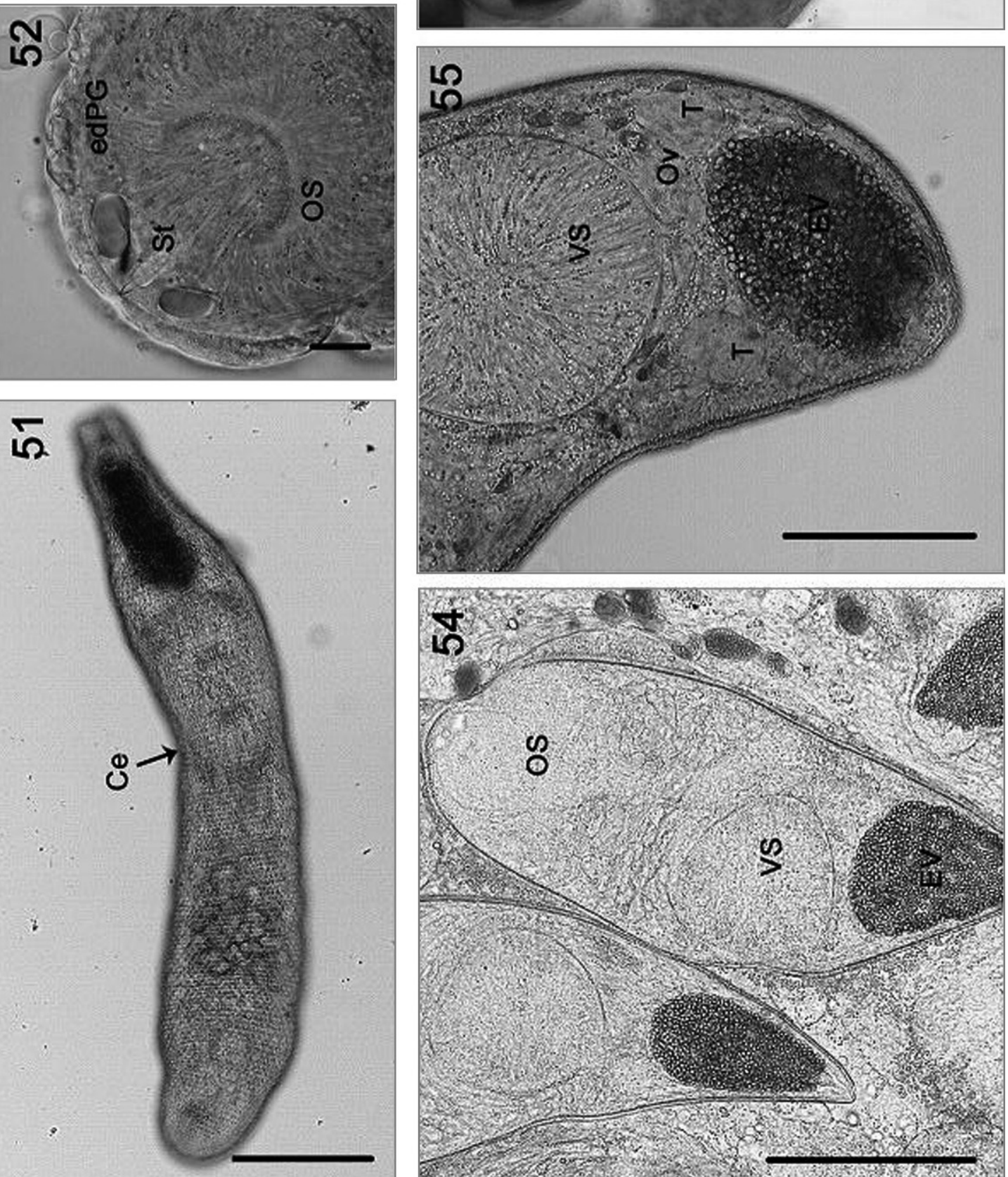

톨

㟧

in

is 00

흐의

क力 ए

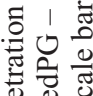

的

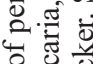

웜

吾 I

0,00

可

可

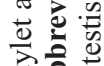

空娄

峲

馬

궁

ति के

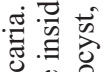

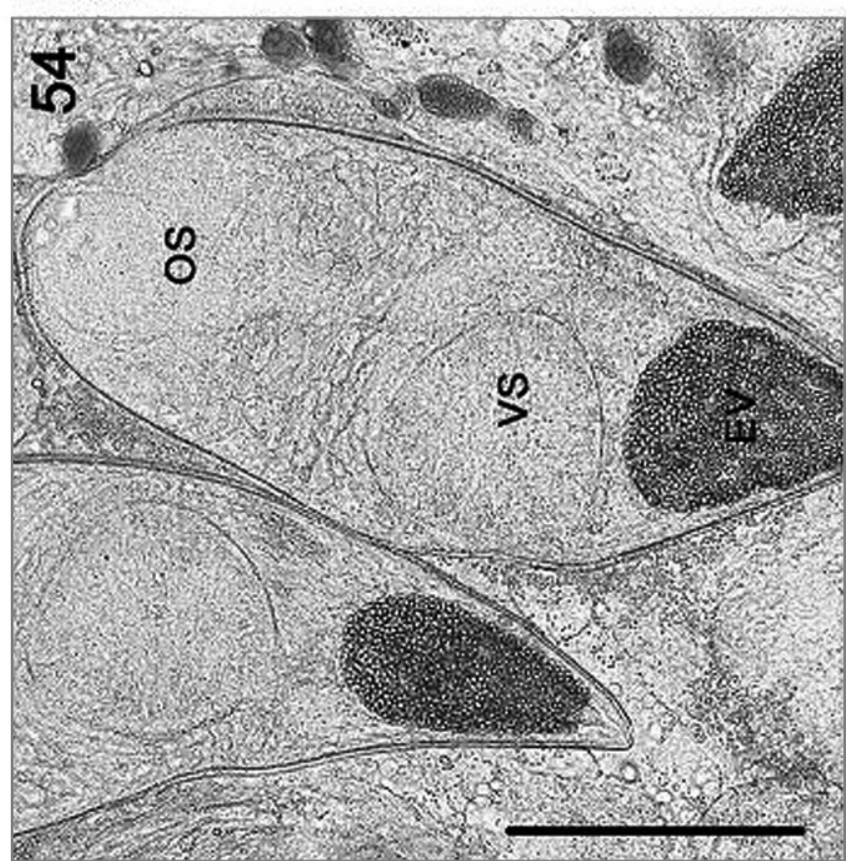

过

U. है क्र

的苛 is

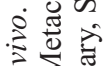

业

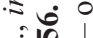

की

踏

son

퓨

$=\frac{\pi}{0}$

जी

\%

论

त

ज

里

ถ⿱㇒冋. 

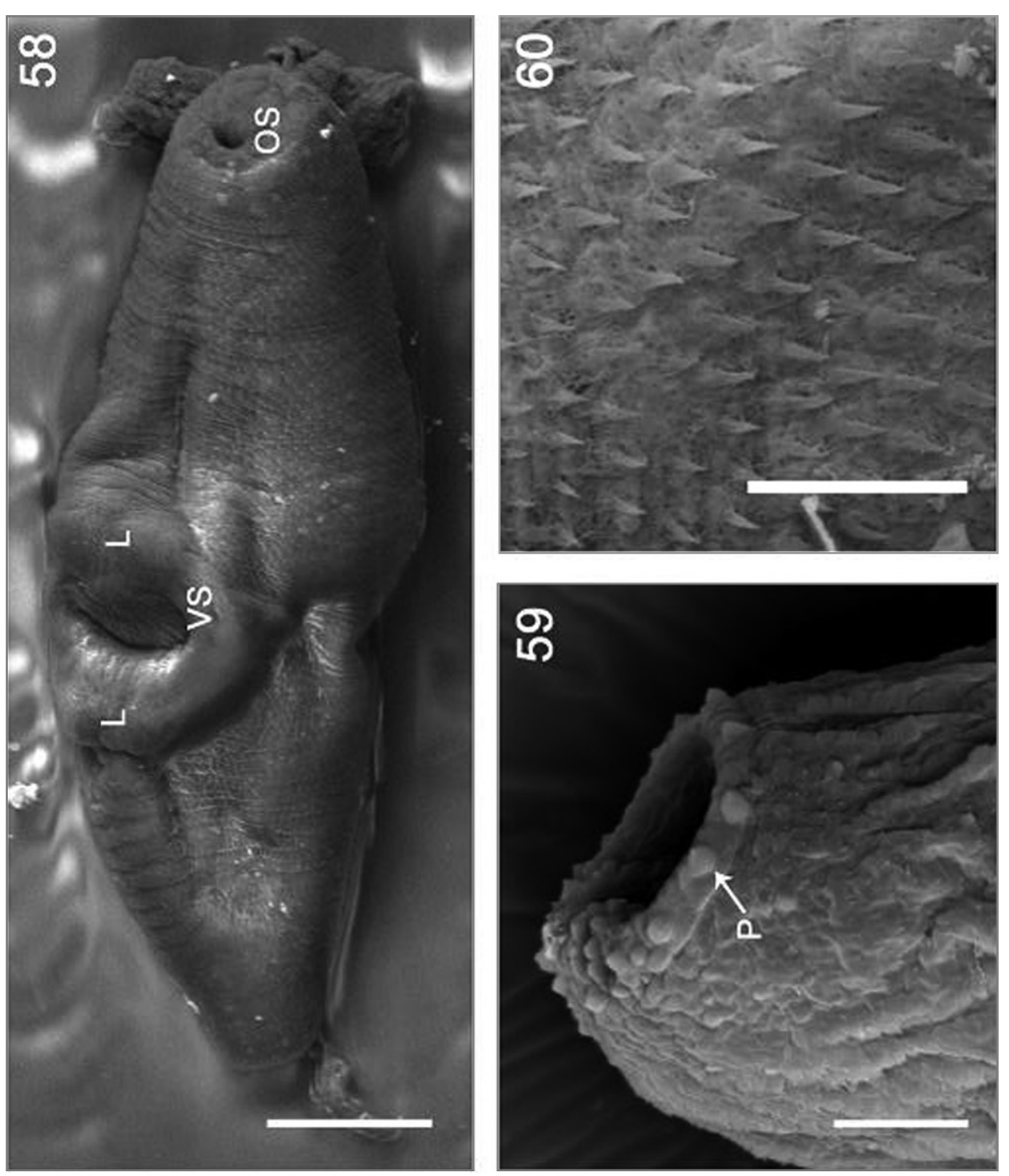

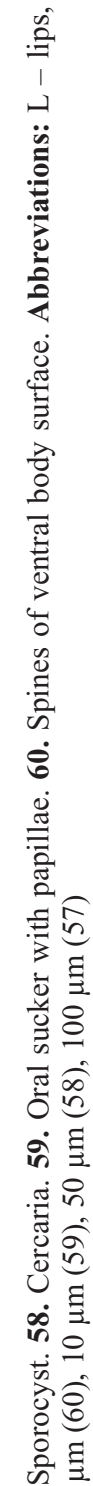
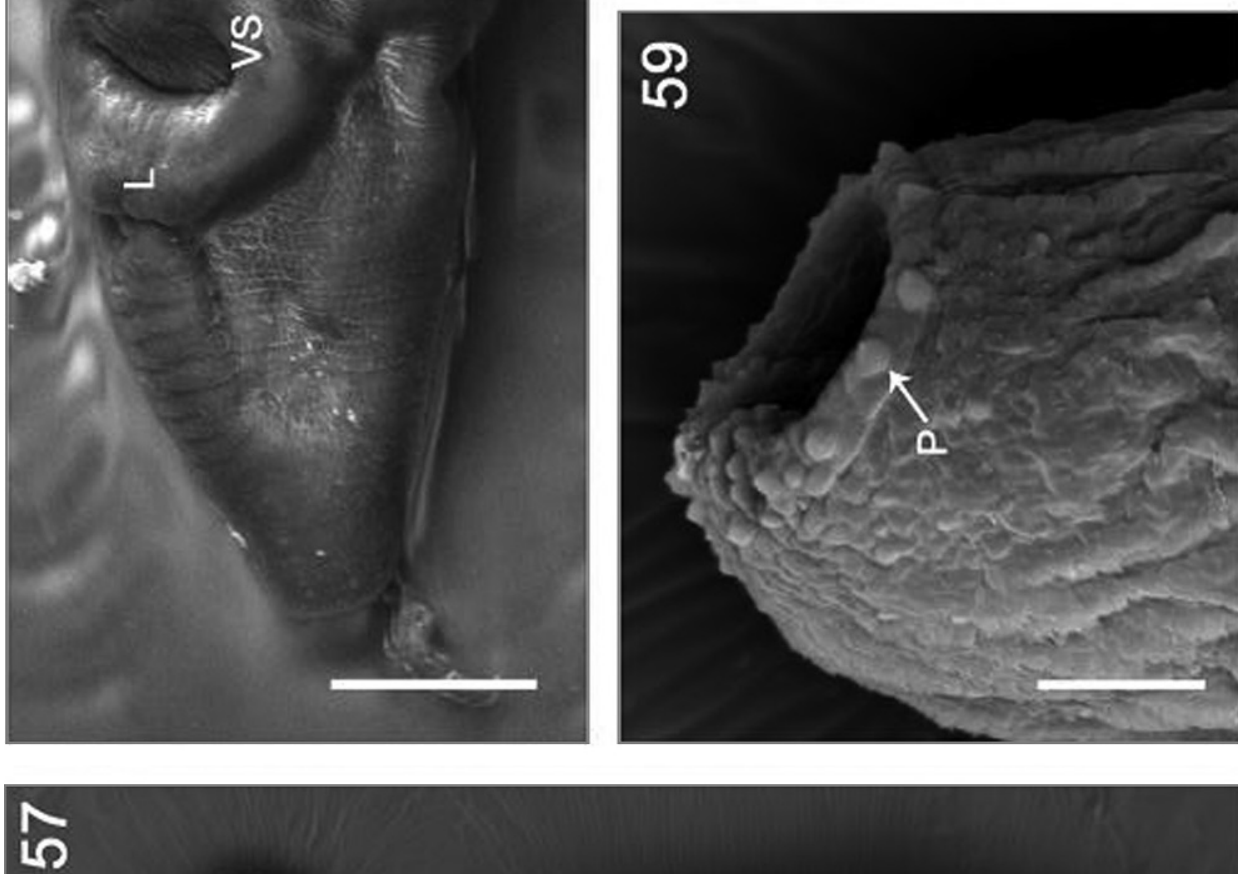

10

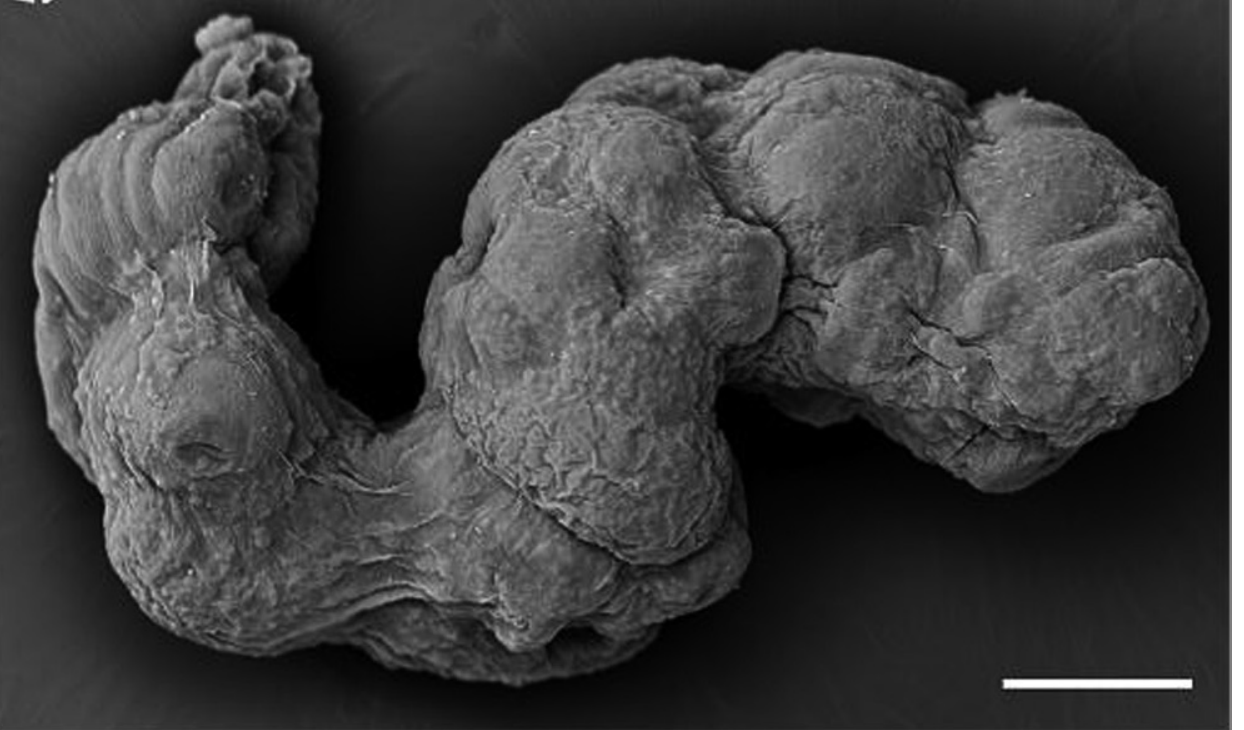

in

$\sum_{\text {in }}$

ส

के

등

ฐิ

需

तथ

is

तै

施

跔 ।

तु

空

들

i $\frac{\pi}{\pi}$

in

㩆哈 
surpassing anterior edge of ventral sucker. Ventral sucker large and strong muscular, 96 (54-143) long by 106 (69-126) wide, with 4 muscular lips ( 2 anterior and 2 posterior), sometimes invaginated (Fig. 53). Three pairs of penetration glands (determinated by openings of ducts), opening ventrally at stylet base. Immature ovary $23(18-30)$ long by $24(20-30)$ wide (n $=5$ ) at left side of body, between ventral sucker and excretory vesicle; two developing testes, at each side, left testis, 27 (2332) long by 21 (17-24) wide, right testis, 29 (25-31) long by $19(17-22)$ wide $(n=3)$ (Fig. 55). Cirrus pouch incompletely developed, located between intestinal caeca. Genital pore opening at left side of body at pharyngeal level. Excretory vesicle oval, 70 (46-86) long by 59 (44-80) wide, filled with refringent granules (Fig. 55). Excretory formula: $2[(2+2+2)]$ $=12$.

Behaviour: Cercariae move actively inside sporocyst and emerge by rupture of the wall. Some cercariae encysted inside the sporocyst were observed. Naturally shed cercariae move rapidly on the bottom of Petri dishes by contracting and stretching the body. Their life-span is less than $24 \mathrm{hs}$ at room temperature, but at lower temperature $\left(10^{\circ} \mathrm{C}\right)$ survival is up to 96 hs.

Metacercaria (Fig. 56): Cyst spherical, 269 (245-285) in diameter, wall 9 (6-13) thick.

Host: Buccinanops globulosus Kiener (Caenogastropoda, Nassariidae).

Prevalence: $0.16 \%(\mathrm{n}=632$, intertidal samples $)$ and $5.1 \%$ $(\mathrm{n}=59$, subtidal sample).

Specimens deposited: 6280-6281 (MLP) and 21-23 (CNPPar).

Comments: The following morphological features define parthenitae here described as belonging to Zoogonidae: tailless xiphidocercariae with large ventral sucker at posterior half of body, cystogenous glands scattered in parenchyma, excretory vesicle saccate filled with excretory granules, 2 opposite testes and a median ovary, cirrous pouch with lateral genital pore. Larvae were identified as belonging to the genus Diphterostomum Stossich, 1903 by the presence of 2 short and divergent caeca (Bray 2008). It is similar to Diphterostomum brusinae, having four lips on the ventral sucker, which are also present in the adult form described by Pina et al. (2009) from northern Portugal.

\section{Discussion}

This study reports 4 new records of larval stages of digeneans parasitising the most common intertidal gastropods from the northern Patagonian coast: Maritrema sp. 1, Parorchis. sp., Renicolidae gen. et sp. and Diphterostomum sp. We also found the larval stages of Maritrema sp. 2 and Hemiuridae gen. et sp., previously described by Alda and Martorelli (2009) from intertidal gastropods occurring $500 \mathrm{~km}$ south of the locale of the present study. In the study area, during the year, both species of Maritrema showed the highest overall prevalences
(33.45\% and $8.95 \%$ ), while the remaining species presented lower values: Hemiuridae larvae $(0.48 \%)$, Parorchis sp. $(0.87 \%)$, Renicolidae larvae $(0.29 \%)$ and Diphterostomum $\mathrm{sp}$. $(0.16 \%)$. Crepidula dilatata harbours the most prevalent species, Maritrema sp. 1. This is the first record of a parasite in gastropods of the genus Crepidula (Pechenik et al. 2001).

Descriptions of larval digeneans represent a valuable contribution toward the understanding of their life cycles on Patagonian coasts. Both species of Maritrema most probably use the kelp gull, Larus dominicanus, as definitive host (Diaz 2006). The cercaria of Maritrema sp. 2 seems to correspond to the metacercariae found in the crab Cyrtograpsus altimanus Rathburn (Grapsidae) (Diaz and Cremonte 2010). From these metacercariae, Diaz and Cremonte (2010) experimentally obtained the adult stage, identified as Maritrema madrynensis Diaz et Cremonte, 2010. The adult corresponding to the larval stages of Hemiuridae here studied could belong to one of the nine species reported parasitising fishes from Patagonian coasts (Kohn et al. 2007). With regard to the cercaria of Parorchis sp., previous worldwide records also reported muricid gastropods as first intermediate hosts (Stunkard and Cable 1932, Cooley 1962). In the study area, adults of Parorchis acanthus were found in L. dominicanus (Diaz 2006), which may correspond to the larval stages found in T. geversianus. At present, there are no records of adult Renicolidae from the Southwestern Atlantic coasts. Only metacercarial stages were found in mytilids (Bivalvia) on the Patagonian coast (Cremonte 1999), these could correspond to the larval stages here reported in T. geversianus. Diphterostomum sp. described in the present study from B. globulosus seem to belong to $D$. brusinae. In a previous parasitological survey of the Brazilian sandperch Pinguipes brasilianus Cuvier (Pinguipedidae) from the present study area, Timi et al. (2008) cited the presence of adult digeneans identified as Opecoelidae gen. et sp. indet. The examination of additional material revealed that, in fact, these adult digeneans actually belong to D. brusinae. In agreement with our findings, the life cycles of D. brusinae studied by Palombi (1930, 1934), Prévot (1966) and Pina et al. (2009), included nassariid gastropods as first intermediate hosts.

Larval trematodes in intertidal snails were reported by many authors (e.g., Curtis 1990, Galaktionov and Skirnisson 2000, Fredensborg et al. 2005). The commonest families found were Microphallidae, Renicolidae, Echinostomatidae, Philophtalmidae, Lepocreadiidae, and Zoogonidae (e.g., Lauckner 1980, Galaktionov and Skirnisson 2000, Fredensborg et al. 2005, Russell-Pinto et al. 2006, Curtis 2007). We found parthenitae corresponding to six species and to five families, Microphallidae (2), Hemiuridae, Philophtalmidae, Renicolidae and Zoogonidae. These species use seabirds (Maritrema sp. 1 and Maritrema sp. 2, Parorchis sp. and Renicolidae) and fishes (Hemiuridae and Diphterostomum sp.) as definitive hosts.

The study of digenean life cycles associated with marine coastal areas is particularly important in regions where infec- 
tion of intertidal molluscs with digeneans is increasing (e.g., Galaktionov and Skirnisson 2000, Hechinger et al. 2008). This phenomenon is related with an increase in the seabird population (mainly gulls) favoured by some human activities (fishing ports, coastal settlements, fish farms, etc.), leading to an increase in parasite pressure on populations of intertidal animals in adjacent coastal regions (Hechinger and Lafferty 2005, Bustnes 2000). However, the high diversity of parasites is an indicator of healthy ecosytems because the conditions to promove the life cycles of digeneans are preserved (Lafferty 1997). In the present case, most of the more prevalent parasites reported upon here, especially the Maritrema species, seem to use the kelp gull as definitive host, reflecting the increase in abundances of gull populations at Puerto Madryn city, due to human activities (Yorio et al. 2005).

Acknowledgements. The authors thank to Jaime Groizard (SEM unit, ALUAR SA) for the SEM photographs and Estefanía Bagnato for her help in the field. This study was funded by ANPCyT (PICT 1374), PIP (CONICET, to F. Cremonte) and N628 (UNLP). Authors are members of CONICET.

\section{References}

Aberbuj A., Cremonte F. 2010. Parasitic castration of Buccinanops cochlidium (Gastropoda: Nassariidae) caused by a lepocreadiid digenean in San Jose' Gulf, Argentina. Journal of Helminthology, 84, 381-389. DOI: 10.1017/S0022149X100 00052.

Alda P., Martorelli S.R. 2009. Larval digeneans of the siphonariid pulmonates Siphonaria lessoni and Kerguelenella lateralis and the flabelliferan isopod Exosphaeroma sp. from the intertidal zone of the Argentinean Sea. Comparative Parasitology, 76, 267-272. DOI: 10.1016/j.ecss.2010.01.012.

Balech E., Ehrlich M.D. 2008. Esquema Biogeográfico del Mar Argentino. Revista de Investigación y Desarrollo Pesquero, 19, $45-75$.

Bray R.A. 2008. Family Zoogonidae Odhner, 1902. In: (Eds.. R.A. Bray, D.I. Gibson and A. Jones) Keys to the Trematoda. Volume 3. Wallingford, CABI Publishing and the Natural History Museum, pp. 605-629.

Bridgman J.F. 1971. The life cycle of Maritrema setoenensis n. sp. (Trematoda: Microphallidae). Japanese Journal of Parasitology, 20, 13-23.

Bush A.O., Lafferty K.D., Lotz J.M., Shostak A.W. 1997. Parasitology meets ecology on its own terms. Margolis et al. revisited. Journal of Parasitology, 83, 575-583. DOI: 10.2307/328 4227.

Bustnes J.O.,Galaktionov K.V., Irwin S.W.B. 2000. Potential threats to littoral biodiversity: is increased parasitism a consequence of human activity? Oikos, 90, 189-190. DOI: 10.1034/j.16000706.2000.900121.x

Cable R.M. 1956. Marine cercariae of Puerto Rico. Scientific Survey of Porto Rico and the Virgin Islands, 16, 491-577.

Cable R.M. 1963. Marine cercariae from Curaçao and Jamaica Zeitschrift für Parasitenkunde, 23, 429-469.

Combes C. 2001. The ecology and evolution of intimate interactions. The University of Chicago Press, Chicago and London, $701 \mathrm{pp}$.
Cooley N.R. 1962. Studies on Parorchis acanthus (Trematoda: Digenea) as a biological control for the southern oyster drill, Thais haemastoma. Fishery Bulletin of the Fish and Wildlife Service, 62, 77-91.

Cremonte F. 1999. Estudio parasitológico de bivalvos que habitan ambientes marinos y mixohalinos en Argentina. Doctoral Thesis, Universidad Nacional de La Plata, La Plata, Argentina, 196 pp.

Cribb T.H., Bray R.A. 2010. Gut wash, body soak, blender and heatfixation: approaches to the effective collection, fixation and preservation of trematodes of fishes. Systematic Parasitology, 76, 1-7. DOI: 10.1007/s11230-010-9229-z.

Curtis L.A. 1990. Parasitism and the movements of intertidal gastropod individuals. Biological Bulletin, 179, 105-112.

Curtis L. 2007. Larval trematode infections and spatial distributions of snails. Invertebrate Biology, 126, 235-346. DOI: 10.1111/ j.1744-7410.2007.00093.x.

Diaz J.I. 2006. Las comunidades parasitarias como expresión de distinto comportamiento trófico en aves del Mar Argentino. Doctoral Thesis, Universidad Nacional de la Plata, La Plata, Argentina, $259 \mathrm{pp}$.

Diaz J.I., Cremonte F. 2010. The development from metacercaria to adult of a new species of Maritrema (Digenea: Microphallidae) parasitic in kelp gull, Larus dominicanus, from Patagonian coast, Argentina. Journal of Parasitology, 96, 740-745. DOI: $10.1645 / \mathrm{GE}-2343.1$.

Etchegoin J.A., Martorelli S.R. 1997. Description of a new species of Maritrema (Digenea: Microphallidae) from Mar Chiquita coastal lagoon (Buenos Aires, Argentina) with notes on its life cycle. Journal of Parasitology, 83, 709-713. DOI: 10.2307/ 3284251 .

Fredensborg B.L., Mouritsen K.N., Poulin R. 2005. Impact of trematodes on host survival and population density in the intertidal gastropod Zeacumantus subcarinatus. Marine Ecology Progress Series, 290, 109-117.

Galaktionov K., Skirnisson K. 2000. Digeneans from intertidal molluscs of SW Iceland. Systematic Parasitology, 47, 87-101. DOI: $10.1023 / \mathrm{A}: 1006426117264$.

Galaktionov K.V., Dobrovolskij A.A. 2003. The biology and evolution of trematodes. An essay on the biology, morphology, life cycles, transmissions, and evolution of digenetic trematodes. Kluwer Academic Publishers, Dordrecht, The Netherlands, $592 \mathrm{pp}$

Graefe G. 1968. Paramonostomum antarcticum n. sp. (Trematoda: Notocotylidae) und Beobachtungen zur Larvenentwicklung in der Antarktis. Zeitschrift für Parasitenkunde, 30, 207-232.

Granovitch A.I., Sergievsky S.O., Sokolova I.M. 2000. Spatial and temporal variation of trematode infection in coexisting populations of intertidal gastropods Littorina saxatilis and $L . o b$ tusata in the White Sea. Diseases of Aquatic Organisms, 41, 53-64.

Hechinger R.F., Lafferty K.D. 2005. Host diversity begets parasite diversity: bird final hosts and trematodes in snail intermediate hosts. Proceedings of the Royal Society B: Biological Sciences, 272, 1059-1066. DOI: 10.1098/rspb.2005.3070.

Hechinger R.F., Lafferty K.D., Kuris A.M. 2008. Trematodes indicate animal biodiversity in the chilean intertidal and Lake Tanganyika. Journal of Parasitology, 94, 966-968.

Holliman R.B. 1961. Larval trematodes from Apalachee Bay area, Florida, with a checklist of known marine cercariae arranged in a key to their superfamilies. Tulane Studies in Zoology, $9,1-74$.

Kohn A., Fernandes B.M.M., Cohen S.C. 2007. South American Trematodes Parasites of Fishes. Ministério da Saúde, Fundação Oswaldo Cruz, Rio de Janeiro, 318 pp. 
Lafferty K.D. 1997. Environmental parasitology: what can parasites tell us about human impacts on the environment? Parasitology Today, 13, 251-255.

Lafferty K.D., Dobson A.P., Kuris A.M. 2006. Parasites dominate food web links. Proceedings of the National Academy of Sciences, 103, 11211-11216. DOI: 10.1073/pnas.0604755103.

Lauckner G. 1980. Diseases of Mollusca: Gastropoda. In: (Ed. O. Kinne) Diseases of Marine Animals. Vol. 1. John Wiley \& Sons, New York, 331-424.

Marcogliese D.J., Cone D.K. 1997. Food webs: a plea for parasites. Trends in Ecology and Evolution, 12, 320-325. DOI: 10. 1016/S0169-5347(97)01080-X.

Martorelli S.R. 1989. Estudios parasitológicos en biotopos lénticos de la República Argentina. V. Desarrollo del ciclo biológico monoxeno de la metacercaria progenética de Genarchella genarchella Travassos, 1928 (Digenea, Hemiuridae) parásita de Littoridina parchappei (Mollusca, Hidrobiidae). Revista del Museo de La Plata (Nueva Serie) Sección Zoología, 14, 109 117.

Martorelli S.R. 1991. Primera cita de una cercaria tricocerca parásita de Dorsanum moniliferum (Mollusca: Buccinidae) para el Atlántico Sud-Occidental. Aportes al conocimiento de su ciclo de vida. Neotrópica, 37, 57-65.

Martorelli S.R. 1994. Una nueva cercaria de tipo cystophorous (Digenea, Hemiuriformes) en Potamolithus agapetus (Mollusca, Hydrobiidae): comportamiento de atracción del hospedador. Iheringia, 76, 15-19.

Martorelli S.R., Fredensborg B.L., Leung T.L.F., Poulin R. 2008. Four trematode cercariae from the New Zealand intertidal snail Zeacumantus subcarinatus (Batillariidae). New Zealand Journal of Zoology, 35, 73-84. DOI: 10.1080/030142208 09510104.

Martorelli S.R., Morriconi E. 1998. A new gymnophallid metacercaria (Digenea) in Nacella $(P$.) magellanica and $N$. $(P$.) deaurata (Mollusca, Patellidae) from the Beagle Channel, Tierra del Fuego, Argentina. Acta Parasitologica, 43, 20-25.

Nicoll W. 1907. Parorchis acanthus, the type of a new genus of trematodes. Quarterly Journal of Microscopical Sciences, 51, $345-355$.

Palombi A. 1930. II ciclo biologico di Diphterostomum brusinae Stossich (Trematode: digenetico: fam. Zoogonidae Odhner)
Considerazioni sui cicli evolutivi delle specie afini e dei trematodi in generale. Pubblicazioni della Stazione Zoologica di Napoli, 10, 111-149.

Palombi A. 1934. Gli stadi larvali dei trematodi del Golfo de Napoli, 1. Contributo allo studio della morfologia, biologia, e sistematica delle cercarie marine. Pubblicazioni della Stazione Zoologica di Napoli, 14, 51-94.

Pechenik I.A., Fried B., Simpkins H.L. 2001. Crepidula fornicata is not a first intermediate host for trematodes: who is? Journal of Experimental Marine Biology and Ecology, 261, 211-224.

Pina S., Tajdari J., Russell-Pinto F., Rodrigues P. 2009. Morphological and molecular studies on life cycle stages of Diphterostomum brusinae (Digenea: Zoogonidae) from northern Portugal. Journal of Helminthology, 83, 321-331. DOI: 10. 1017/S0022149X09250796.

Prévot G. 1966. Sur deux trématodes larvaires d'Antedon mediterranea Lmk. (Echinoderme): Metacercaria sp. (Monorchiidae) Odhner, 1911 et métacercaire de Diphterostomum brusinae Stoss., 1904 (Zoogonidae Odhner, 1911). Annales de Parasitologie, 41, 233-242.

Russell-Pinto F., Gonçalver J.F., Bowers E. 2006. Digenean larvae parasitizing Cerastoderma edule (Bivalvia) and Nassarius reticulatus (Gastropoda) from Ria de Aveiro, Portugal. Journal of Parasitology, 92, 319-332. DOI: 10.1645/GE-3510.1.

Sannia A., James B.L. 1977. The Digenea in marine molluscs from Eyjafjördur, North Iceland. Ophelia, 16, 97-109.

Stunkard H.W., Cable R.M. 1932. The life history of Parorchis avitus (Linton) a trematode from the cloaca of the gull. Biological Bulletin, 62, 328-338

Timi J.T., Lanfranchi A.L., Etchegoin J.A., Cremonte F. 2008. Parasites of the Brazilian sandperch Pinguipes brasilianus Cuvier: a tool for stock discrimination in the Argentine Sea. Journal of Fish Biology, 72, 1332-1342. DOI: 10.1111/j.1095-8649. 2008.01800.x

Yamaguti S. 1975. A synoptical review of life histories of digenetic trematodes of vertebrates with special reference to the morphology of their larval forms. Keigaku Publishing Co Tokyo, $575 \mathrm{pp}$.

Yorio P., Bertelotti M., García Borboroglu P. 2005. Estado poblacional y de conservación de gaviotas que se reproducen en el Litoral Marítimo Argentino. Hornero, 20, 53-74. 